\title{
FinANCING INNOVATION: LEGAL DEVELOPMENT OF Intellectual Property as SeCURity in FinANCING, 1845-2014
}

\author{
XUAN-THAO NGUYEN*
}

\section{INTRODUCTION}

Commentators have repeatedly raised questions about the United States' ability to continue to be an innovative nation. ${ }^{1}$ Some complained that compared to other countries with higher rates on innovation, the United States has fallen behind due to lack of funding for research. ${ }^{2}$ Small businesses, known for being incubators of new ideas and job creation, continue to face major obstacles in obtaining government funding and financing from lenders. ${ }^{3}$ While lenders are willing to extend credit to large businesses, they often ignore small businesses. ${ }^{4}$

* Professor Xuan-Thao Nguyen is the Gerald L. Bepko Chair in Law and Director of Center for Intellectual Property \& Innovation, Indiana University Robert H. McKinney School of Law. Special thanks to all the participants at the Vietnam Ministry of Science and Technology and Vietnam Institute of Intellectual Property Research at the workshop on financing innovation. Many thanks to Reid E. Dodge, Editor in Chief of the Indiana Law Review, for inviting me to contribute this article. I dedicate this article to Erik Darwin Hille and Khai-Leif Nguyen-Hille; their unconditional love and support allowed my smooth transition to Indiana University.

1. See U.S. DeP'T OF COMMERCE, The COMPETITIVENESS AND INNOVATIVE CAPACITY OF THE UNITED STATES (2012), available at http://www.commerce.gov/sites/default/files/documents/ 2012/january/competes_010511_0.pdf, archived at http://perma.cc/Z7QP-NV5W [hereinafter COMMERCE REPORT] (“[A]larms began to sound about the U.S. economy's ability to remain [in its past position].... Observers have expressed concern that the scientific and technological building blocks critical to our economic leadership have been eroding . . . ."); see generally NAT'L ECON. COUNCIL, THE White House's STRATEgy FOR AMERICAN INNOVATION (2009), available at http://www.whitehouse.gov/administration/eop/nec/StrategyforAmericanInnovation, archived at http://perma.cc/G26Q-E7J9 (attempting to address the innovation issue with a grand plan to set the country on a multi-approach path); Harold L. Sirkin, Has the U.S. Lost Its Innovation Edge, BLOOMBERG BUSINESSWEEK (Jan. 21, 2014), http://www.businessweek.com/articles/2014-0121/has-america-lost-is-innovation-edge, archived at http://perma.cc/MN7V-LY9Y (noting that "only one in five of the 1,500 executives who participated in the fall 2013 survey rated their company's innovation performance as strong ....").

2. See generally Eamonn Fingleton, America the Innovative?, N.Y. TIMES, Mar. 30, 2013, http://www.nytimes.com/2013/03/31/sunday-review/america-the-innovative.html?pagewanted=all, archived at http://perma.cc/X8Q4-7QVM (stating that funding for research was the reason for American's mid-twentieth Century rise in innovation and lacking funding today will negatively impact American's innovation pace).

3. See, e.g., COMMERCE REPORT, supra note 1.

4. Karen Gordon Mills \& Brayden McCarthy, The State of Small Business Lending: Credit Access During the Recovery and How Technology May Change the Game 4-6 (Harvard Business School, Working Paper No. 15-004), available at http://www.hbs.edu/faculty/Publication\% 
The dire financing situation faced by small businesses today is similar to the credit squeeze during and after the epic financial crisis in $2009 .{ }^{5}$

Without funding from both public and private sectors, small businesses cannot operate their companies, innovate for new ideas, and foster employment growth. ${ }^{6}$ The United States may soon lose its edge in innovation. How can financing be made available for small businesses that most often own neither real property nor tangible assets?

Small businesses have ideas, trademarks, content, know-hows, and other intangible assets. ${ }^{7}$ These intangible properties can be used as collateral to obtain financing from the private sector. ${ }^{8}$ Lenders must be willing to accept this type of property as collateral in order for credits to be extended to small businesses. Creditors must overcome their reluctance in these commercial transactions. This Article argues that lenders should take great comfort in making loans to small businesses with intellectual property assets serving as collateral. The United States has a long legal history of paving the path for financing innovation, as seen through the development of decisional law spanning from 1845 to the present. ${ }^{9}$ The established history of lending with intellectual property collateral is uniquely American. ${ }^{10}$ Recourses and remedies under strong rules of law system are readily available for secured lenders and creditors who are willing to finance innovation. $^{11}$

The Article proceeds as follows. Part I traces the development of embracing patents, copyrights and trademarks in chattel mortgages. This part analyzes early cases, including the seminal case, Waterman $v$. Mackenzie, ${ }^{12}$ in patent mortgages, and their significance in recognizing the incorporeal property and the right of the mortgagee. Additionally, Part I focuses on the development in copyright statutes in relation to the use of copyrights in mortgages. Most importantly, the arrival of new technologies necessitated the increase of financing for the creation and distribution of copyrighted content and legal developments in the area of foreclosure of copyright mortgages. ${ }^{13}$ Part I also examines whether trademarks were used in chattel mortgages during the similar period of patent and copyright

20Files/15-004_09b1bf8b-eb2a-4e63-9c4e-0374f770856f.pdf, archived at http://perma.cc/8PUSSZ97.

5. See id. at 8-10 (studying the lending patterns to small businesses before and after the 2008 economic recession).

6. See, e.g., COMMERCE REPORT, supra note 1, at 3-6.

7. See, e.g., id.

8. See, e.g., id.

9. See Wilson v. Rousseau, 30 F. Cas. 162, 182 (Cir. Ct. N.D.N.Y. 1845).

10. See Jay M. Mattappally, Goliath Beats David: Undoing the Leahy-Smith America Invents Act's Harmful Effects on Small Businesses, 58 LoY. L. REV. 981, 987-91 (2012).

11. See Van Well Nursery, Inc. v. Mony Life Ins. Co., 362 F. Supp. 2d 1223, 1224 (E.D. Wash. 2005).

12. Waterman v. Mackenzie, 138 U.S. 252 (1891).

13. See Republic Pictures Corp. v. Security-First Nat'l Bank of L.A., 197 F.2d 767, 770 (9th Cir. 1952). 
mortgages. Due to the nature of trademarks, the stricter view of trademarks and their attached goodwill, trademark mortgages faced certain limitations. ${ }^{14}$ Recognizing the limitations of trademark mortgages, this section compares how patent, copyright and trademark provisions differ statutorily in their recording requirements for mortgages.

Part II moves to the post-war period of robust economic growth and commercial law reform nationwide. The adoption of Article 9 of the Uniform Commercial Code marks a new era of creating uniform law for states to encourage financing based on personal property as the backbone of economic growth. ${ }^{15}$ Paralleling the development in uniform commercial law, historic milestones in intellectual property law are seen through the overhauls in trademark law, patent law, and copyright law that modernized intellectual property law. ${ }^{16}$ Part II traces the intersection of Article 9 of the Uniform Commercial Code and intellectual property law. This intersection led to new approaches to patent collateral, copyright collateral, and trademark collateral. ${ }^{17}$ Particularly, the old mortgages were replaced with a new understanding and practice of security interest in modern secured transactions. ${ }^{18}$ In addition, challenging issues relating to whether federal or state law will govern perfection of intellectual property must be resolved in order for financing based on intellectual property to flourish. ${ }^{19}$

Part III looks beyond financing based on intellectual property in the private sector. This part will examine the United States' government's role in financing small businesses with intellectual property assets. The United States Small Business Administration has a history of extending loans to small businesses and accepting intellectual property as security for the repayment of loans. ${ }^{20}$ This section will analyze decisional law for a comprehensive understanding of both the practice and legal development of the government's financing for small business innovation.

Part IV shifts to contemporary issues arising in financing innovation. Specifically, this part dissects the recourse and remedies available to secured creditors in financing innovation when the borrower could not fulfill payment obligations. This part analyzes recent Federal Circuit decisions determining whether a secured party of intellectual property collateral becomes the owner of the intellectual property by operation of law in post default. Predictability as to ownership of intellectual property collateral in post default will enhance financing

14. See In re Leslie-Judge Co., 272 F. 886, 887-88 (2d Cir. 1921).

15. See Adam J. Levitin, The Paper Chase: Securitization, Foreclosure, and the Uncertainty of Mortgage Title, 63 DuKE L.J. 637, 697 (2013).

16. See Harold R. Weinberg \& William J. Woodward, Jr., Easing Transfer and Security Interest Transactions in Intellectual Property: An Agenda for Reform, 79 KY. L.J. 61, 62-65 (1990).

17. Xuan-Thao Nguyen, Collateralizing Intellectual Property, 42 GA. L. REV. 1, 5 (2007).

18. Id. at 16 .

19. Id. at 25 .

20. Railex Corp. v. Joseph Guss \& Sons, Inc., 40 F.R.D. 119, 121 (D.D.C. 1966). 
of innovation. ${ }^{21}$

There are some risks associated with financing innovation. ${ }^{22}$ Part V identifies and assesses the risks. Notably, the risks include whether a grant of security interest in some circumstances is deemed a fraudulent transfer and whether the secured creditor is liable for infringement. ${ }^{23}$ However, these risks are rare in financing innovation by the private sector. ${ }^{24}$

Learning from the development of financing innovation from 1845 to the present, Part VI offers observations and discusses implications for future financing of innovation. There is a need for both traditional and online lenders to appreciate the intellectual property assets held by small businesses. ${ }^{25}$ The intellectual property assets should be included in the analytics in assessing the overall health of a business seeking a loan or a line of credit for its new innovative product, idea, or vision. ${ }^{26}$ The Article ends with a brief conclusion that in order to maintain the United States' innovative edge, attention to the access to financing by small businesses must be at the center of the discussion, and intellectual property must be recognized as part of that center.

\section{EMBRACING INTELLECTUAL PROPERTy MORTGAGES}

In 1790, Congress passed the first patent and copyright statutes during its very first year of governing the new country. ${ }^{27}$ Appreciating the importance of intellectual property in the development of the new nation, the new statutes and subsequent amendments provided a uniform system relating to the eligibility for receiving legal protection, duration of protection, infringement, remedies and transfers of ownership. ${ }^{28}$ The idea of using patents, copyrights and trademarks

21. See Aptix Corp. v. Quickturn Design Sys., Inc., 148 F. App’x 924, 928-30 (Fed. Cir. 2005).

22. Id.

23. Id.

24. See Nguyen, supra note 17 , at 36 .

25. Mills \& McCarthy, supra note 4 , at 4 .

26. Id. at 42-44.

27. See generally Camilla A. Hrdy, State Patent Laws in the Age of Laissez Faire, 28 BERKELEY TeCH. L.J. 45 (2013) (stating that Congress passed the first federal Patent Act of 1790 providing inventors with a term of protection for fourteen years); Dotan Oliar, Making Sense of the Intellectual Property Clause: Promotion of Progress as a Limitation on Congress's Intellectual Property Power, 94 GEO. L.J. 1771 (2006) (tracing the development of the patent and copyright clause in the Constitution and congressional power in enacting federal laws on patents and copyrights); Edward C. Walterscheid, Understanding the Copyright Act of 1790: The Issue of Common Law Copyright in America and the Modern Interpretation of the Copyright Power, $53 \mathrm{~J}$. COPYRIGHT SOC'Y U.S.A. 313 (2006) (analyzing the early debate of whether the rights associated with the patent and copyright clause were inherent or created rights).

28. See Patent Act of 1790, ch. 7, 1 Stat. 109-112 (1790), available at http://ipmall.info/ hosted_resources/lipa/patents/Patent_Act_of_1790.pdf,archived at http://perma.cc/M5VU-C9B7 (current version at 35 U.S.C. $\S \S 1$ to -2071 (2014), available at http://www.uspto.gov/web/offices/ 
as security for payment obligations did not exist during the late eighteenth century, but the use of chattel or personal property ${ }^{29}$ as security for debt or chattel mortgage was common practice. ${ }^{30}$

Chattel mortgage transactions and law developed during the Colonial America period. ${ }^{31}$ In a chattel mortgage, the mortgagor conveyed to the mortgagee the right, title and interest in the chattels to secure the payment of a debt, upon condition that the transfer would be voided by the mortgagor's subsequent timely payment of the debt. ${ }^{32}$ The chattel mortgage financing allowed

pac/mpep/consolidated_laws.pdf, archived at http://perma.cc/YF75-3F9V). Some critics have argued that the United States government has recognized the importance of intellectual property and purposefully created patent law and amendments to protect the interests of domestic businesses and inventors. See William Hubbard, Competitive Patent Law, 65 FLA. L. REV. 341, 356-58 (2013) (observing specific patent statutory provisions that protect domestic interests in patents against foreign businesses and inventors).

29. See, e.g., George Lee Flint, Jr., Secured Transactions History: The Fraudulent Myth, 29 N.M. L. REV. 363, 398 (1999) (tracing the history of chattel mortgage as far back as in "1682 the Connecticut General Court upheld a chattel mortgage, a nonpossessory secured transaction but with possession in a third party, the debtor's agent, on a tannery's inventory and equipment against a levying judgment lien."); George Lee Flint, Jr. \& Marie Juliet Alfaro, Secured Transactions History: The Impact of Southern Stable Agriculture on the First Chattel Mortgage Acts in the Anglo-American World, 30 OHIO N.U. L. REV. 537, 542-43 (2004) (asserting that early Colonial America adopted various chattel mortgage statutes for nonpossessory secured transactions with filing requirements); see also Conard v. Ins. Co., 26 U.S. 386, 391-92 (1828) (discussing the existence of mortgage practices in which property served as security that was not real estate).

30. Andrew R. Berman, "Once a Mortgage, Always a Mortgage”-The Use (and Misuse of) Mezzanine Loans and Preferred Equity Investments, 11 StAn. J.L. Bus. \& Fin. 76, 89 (2005) (stating that "all of the British North American colonies that later became states adopted the wholesale use of mortgages and based their mortgage law on the common law of England.").

31. See George Lee Flint, Jr. \& Marie Juliet Alfaro, Secured Transactions History: The First Chattel Mortgage Acts in the Anglo-American World, 30 WM. MitCHELL L. REV. 1403, 1406-07 (2004) (providing a historical account of chattel mortgage statutes adopted by states in early Colonial American period and noting that a striking feature of these chattel mortgage acts adopted by various states was the filing requirement); see also Mortgage, Chattel-Title to Increase, 1 HARV. L. REV. 306, 306 (1888) (noting that under the then Maryland Code a chattel mortgage is good without possession if it is recorded).

32. Farnum v. Metcalf, 62 Mass. 46, 46 (1851) (“A mortgage, made by A. to B., was assigned by B. to C., to secure a debt, upon condition that if B. should pay the debt, the assignment should determine and become void, and the assigned premises should revest in B., his heirs and assigns."); Carter v. Rewey, 22 N.W. 129, 129 (Wis. 1885) (recognizing a chattel mortgage in the following transaction: "It is in the usual form of a chattel mortgage. For the purpose of securing the payment of $\$ 1,000$, Charles H. McLean bargained, sold, and transferred to the plaintiffs all of his stock in trade - consisting of a quantity of jewelry - and other personal property named, upon the condition that if McLean should forthwith pay the three debts specified, amounting to the sum of $\$ 385$, also to secure such other claims against him as might come into the hands of the plaintiffs for collection, and a claim of Aiken, Lambert \& Co. of \$127, then the sale to be void.”); see also Erskine v. 
individuals and businesses to gain access to financing and reduced the lender's risks. $^{33}$

After the American Revolution, intellectual property assets slowly became important and valuable, and lenders began to accept them in chattel mortgages. ${ }^{34}$ Questions regarding the scope of a mortgagee's right in the mortgaged intellectual property arose in due course. ${ }^{35}$ The mortgagee wanted to know whether they could bring an infringement suit against others during the time period when the mortgagor had not fulfilled the payment obligations ${ }^{36}$ and whether recording a patent mortgage would vest the mortgagee with the entire title in the patent. ${ }^{37}$ Another unanswered question was, under federalism separating the jurisdictions of federal and state courts, which law would govern the foreclosure of mortgaged patents and copyrights. ${ }^{38}$ In addition, there was not a settled opinion as to whether trademarks should be mortgaged like patents and copyrights. ${ }^{39}$ Early cases addressed these questions, thereby widening the path for financing with the use of intellectual property in mortgages. ${ }^{40}$

\section{A. Patent Mortgages}

The United States Supreme Court widely opened the door for financing with the use of patent assets as security in the famous Waterman v. Mackenzie decision in $1891 .{ }^{41}$ In that case, Mrs. Waterman borrowed $\$ 6500$ from Asa L. Shipman

Townsend, 2 Mass. 493, 494 (Mass. 1807) (recognizing a land mortgage wherein the defendant "pleads a bond dated the same day, in the penal sum of 500 dollars, with a condition-after reciting that the defendant, owing the plaintiff 241 dollars 30 cents, and for the better securing the payment of the same, had conveyed to the plaintiff fifty acres of land - that, if the defendant should pay the plaintiff that sum in six months, and the plaintiff shall then reconvey the land to the defendant, the bond was to be void.").

33. Flint \& Alfaro, supra note 31 , at 562, 570 (demonstrating how oversea merchants from England and the Netherlands were eager to lend to planters in Virginia and took security in personalty, including "indentured servants, goods and bills of exchange" and that the booming plantation economy paved the way for small planters to seek "greater wealth through expansion based on secured loans").

34. See infra Part I.A-C.

35. See generally Waterman v. Mackenzie, 138 U.S. 252 (1891).

36. Id.

37. Id.

38. See generally Republic Pictures Corp. v. Security-First Nat'1 Bank of L.A., 197 F.2d 767 (9th Cir. 1952).

39. See generally Morgan v. Rogers, 19 F. 596 (Cir. Ct. D.R.I. 1884).

40. Id.

41. Waterman, 138 U.S. at 258. Patents as security for loans occurred for quite some time before the United States Supreme Court decided its Waterman decision. See Wilson v. Rousseau, 30 F. Cas. 162, 182 (Cir. Ct. N.D.N.Y. 1845) (observing that "[a] patentee having mortgaged the patent-right, continued in the notorious use of it, until he became bankrupt"); Hollins \& Napier v. Mallard, 10 How. Pr. 540 (N.Y. Sup. Ct. 1854) (holding that the mortgagee has a lien on the patents 
$\&$ Son on November $25,1884 .{ }^{42}$ To secure the payment on the promissory note, Mrs. Waterman mortgaged the patent relating to inventions of fountain pens obtained by her inventor-husband by executing a conditional assignment, which contained an express provision that the assignment should be null and void if the payment obligation was paid on the due date. ${ }^{43}$ As mortgagee, Asa L. Shipman $\&$ Sons and its subsequent assignee, Asa L. Shipman, timely recorded the patent mortgage with the Patent Office. ${ }^{44}$ Mr. Waterman transferred the ownership in the patents to his wife on February 13, 1884, received a license to manufacture under the patents from his wife on November 20,1884, and brought a patent infringement action against an alleged infringer. ${ }^{45}$ The alleged infringer in turn challenged the plaintiff for lack of standing to maintain the suit, as the patents had already been mortgaged. ${ }^{46}$ At the time of the infringement suit, Mrs. Waterman had not fulfilled the payment obligation to Asa L. Shipman. ${ }^{47}$

By recording the patent mortgage with the Patent Office, the Court ruled that the entire title in the patent, both in law and equity, was acquired by the mortgagee, Asa L. Shipman. ${ }^{48}$ Therefore, the mortgagee enjoyed all rights in the mortgaged patents, including the right to maintain a patent infringement action. ${ }^{49}$ The Court began its analysis by first recognizing that the executed "assignment" between Mrs. Waterman and Asa L. Shipman was an "instrument, being a conveyance made to secure the payment of a debt, upon condition that it should be avoided by the subsequent payment of that debt at a time fixed, was a mortgage, in apt terms, and in legal effect." ${ }^{50}$

The Court then distinguished mortgages in personal property, like patents, from those of real estate. ${ }^{51}$ The Court observed that in real estate financing, the mortgagor has possession of the land and is the equitable owner of the property and the mortgagee has either bare legal title or merely a lien on the property, depending on state laws. ${ }^{52}$

for a regulator and an improvement in gas burners); Moran v. Strauss, 6 Ben. 249 (S.D.N.Y. 1872) (mentioning that the patents were assigned to the defendants as security for the loan).

42. Waterman, 138 U.S. at 257.

43. Id.

44. Id.

45. Id.

46. Id. at 252 .

47. Id. at 257-58.

48. Id. at 260 .

49. Id. at 261 .

50. Id. at 258 .

51. Id. at 258-60.

52. Id. at 258-59 ("A mortgage of real estate has gradually, partly by the adoption of rules of equity in courts of common law, and partly by express provisions of statute, come to be more and more considered as a mere security for the debt, creating a lien or encumbrance only, and leaving the title in the mortgagor, subject to alienation, levy on execution, dower, and other incidents of a legal estate; but the rules upon the subject vary in different states, and a mortgage is everywhere considered as passing the title in the land, so far as may be necessary for the protection 
In personalty mortgages, however, the Court noted that "it is not merely the possession or a special property that passes; but, both at law and in equity, the whole title is transferred to the mortgagee, as security for the debt."53 That meant the personalty mortgagee enjoyed both the equitable title and the legal title to the personal property. ${ }^{54}$ The whole title is subject "only to be defeated by performance of the condition" described in the mortgage instrument. ${ }^{55}$ In other words, the law for personalty mortgage is clearly different from the law for pledges and realty mortgage. ${ }^{56}$ Although the personalty mortgagee does not have possession of the property like in pledges, the entire title to the property has already passed to the mortgagee to secure the loan provided to the mortgagor from the mortgagee. ${ }^{57}$

Moreover, the Court stated, "a recording of the mortgage is a substitute for, and (unless in case of actual fraud) equivalent to, a delivery of possession, and makes the title and the possession of the mortgagee good against all the world." 58 That meant if the mortgagee adheres to the recording statute for personalty mortgage, the mortgagee will be accorded with possessory rights and the recording serves as notice to all for priority purposes. ${ }^{59}$

Applying to the case at hand, noting that a patent right is "incorporeal property," the Court commented that neither actual delivery nor possession could occur. ${ }^{60}$ Therefore, the recording of the patent mortgage with the United States Patent Office in accordance with patent law "is equivalent to a delivery of possession, and makes the title of the mortgagee complete towards all other persons, as well as against the mortgagor."

In deciding the scope of the patent mortgagee's rights, the Court analogized

of the mortgagee, and to give him the full benefit of his security.").

53. Id. at 258 .

54. Id. at 260-61.

55. Id. (observing the right of the mortgagee in the patented mortgage is "only to be defeated by performance of the condition, or by redemption on bill in equity within a reasonable time, and the right of possession, when there is no express stipulation to the contrary, goes with the right of property.").

56. Id.

57. Id. (citing Story, Bailm $\S 287 ; 2$ Story, Eq. Jur. $\S \S 1030,1031$; Casey v. Cavaroc, 96 U.S. 467, 477 (1877); Conard v. Atl. Ins. Co. of N.Y., 26 U.S. 386 (1828); Brackett v. Bullard, 53 Mass. 308 (1847); Boise v. Knox, 51 Mass. 40 (1845)).

58. Id. at 260; see also Patent Act of 1870, Ch. 230, 16 Stat. 198-217 (1870), available at http://ipmall.info/hosted_resources/lipa/patents/Patent_Act_of_1870.pdf, archived at $\mathrm{http}: / /$ perma.cc/8B2Z-LEJR (prescribing that the recording requirement for "assignment, grant, or conveyance" and these transactions "shall be void as against any subsequent purchaser or mortgagee for a valuable consideration, without notice, unless it is recorded in the patent office within three months from the date thereof').

59. Waterman, 138 U.S. at 260.

60. Id.

61. Id. 
and distinguished patent mortgages from land mortgages. ${ }^{62}$ The Court observed that, in a land mortgage transaction, even without possession of the land, the mortgagee may obtain an "action for an injury to his interest," an injunction or damages for activities as "tends to impair the value of the mortgage security, or as is not allowed by good husbandry or by express or implied license from the mortgagee." ${ }^{63}$ Most importantly, only the mortgagee had standing to maintain suit, "and not by the mortgagor or any one claiming under a subsequent conveyance from him." ${ }^{\prime 64}$ In a patent mortgage, however, the Court is concerned about patent rights. ${ }^{65}$ Unlike land rights, the right conferred by a patent is limited in years, and the patent's value is primarily "in the profits derived from royalties and license fees."

In analogy to the rules governing mortgages of lands and of chattels, and with even stronger reason, the assignee of a patent by a mortgage duly recorded, whose security is constantly wasting by the lapse of time, must be held (unless otherwise provided in the mortgage) entitled to grant licenses, to receive license fees and royalties, and to have an account of profits or an award of damages against infringers. ${ }^{67}$

Accordingly, the Court held that the patent mortgagee is accorded the status of "the party interested, either as patentee, assignee, or grantee," and has the right to bring suit against others at law and suit in equity "to recover damages for an infringement. ${ }^{\circ 8}$ Consequently, in the present case, the patent mortgagee, Asa L. Shipman, was entitled to maintain an infringement action against others. ${ }^{69}$ Mrs. Waterman therefore had no standing because she had already mortgaged the patents to Asa L. Shipman. ${ }^{70}$ In reaching a conclusion, the Court explicitly rejected the law propounded under the English Judicature Act of 1873 and the Patent Act of 1883 wherein only the mortgagor of a patent was allowed to maintain a suit for infringement. ${ }^{71}$

62. Id. at 258-59.

63. Id. at 259.

64. Id. at 259 (citing Wood v. Weimar, 104 U. S. 786 (1881); Conard v. Atl. Ins. Co. of N.Y., 26 U.S. 386 (1828); Clapp v. Campbell, 124 Mass. 50 (Mass. 1877)).

65. Id.

66. Id. at 260 .

67. Id. at 261 .

68. Id. at 260 (ruling that the patent mortgagee is the person of interest and further asserting that "it cannot have been the intention of congress that a suit in equity against an infringer to obtain an injunction and an account of profits, in which the court is authorized to award damages, when necessary to fully compensate the plaintiff, and has the same power to treble the damages as in an action at law, should not be brought by the same person").

69. Id. at 260-61.

70. Id. at 261 .

71. Id. ("In the light of our legislation and decisions, no weight can be given to the case of Van Gelder v. Society, 44 Ch. Div. 374, in which, upon pleadings and facts similar to those now before us, the mortgagor of a patent was treated as a mortgagor in possession, and was allowed to 
Waterman v. Mackenzie is significant for several reasons. First, land and real estate are no longer the only security property for secured financing. ${ }^{72}$ Second, creditors are willing to extend loans to debtors with patents and other personal property served as security. ${ }^{73}$ Third, the mortgagee can enjoy all of the debtor's rights, title, and interest in the patent if the mortgagee properly recorded the patent mortgage. ${ }^{74}$ The rights in the patents cover the right to grant licenses, to collect fees and royalties, and to receive damages and accounting of profits against infringers. ${ }^{75}$ Fourth, the patent mortgagee has standing to maintain suit against others for infringement of the mortgaged patent. ${ }^{76}$ Consequently, the mortgagee would be able to reduce its exposure in the event the debtor fails to make payment. ${ }^{77}$ Also, the mortgagee's rights in the patent mortgage accords it with the status of "the party interested" similar to patentee, assignee, or grantee during the entire time while the patent serves as collateral for the mortgage transaction. ${ }^{78}$ Overall, Waterman v. Mackenzie encourages the financial industry to provide financing to individuals and entities with patents that could be used in chattel mortgage financing. ${ }^{79}$

\section{B. Copyright Mortgages}

Patents were not the only type of intellectual property eligible for mortgages in the nineteenth century. ${ }^{80}$ Copyright mortgages were associated with book and music publishing. ${ }^{81}$ Moreover, copyright laws during this time mentioned

maintain a suit for infringement, under the provisions of the English Judicature Act of 1873 and Patent Act of 1883. St. 36 \& 37 Vict. c. $66, \S 25 ; 46 \& 47$ Vict. c. $57, \S \S 23,46,87$. Whether, in a suit brought by the mortgagee, the court, at the suggestion of the mortgagor, or of the mortgagee, or of the defendants, might, in its discretion, and for the purpose of preventing multiplicity of suits or miscarriage of justice, permit or order the mortgagor to be joined, either as a plaintiff or as a defendant, need not be considered, because no such question is presented by this record.").

72. Id.

73. $I d$.

74. Id.

75. $I d$.

76. Id.

77. Id.

78. Id.

79. Notably, in cases decided post-Waterman, the mortgages increased from large amount of loans involving intellectual property collateral. See, e.g., United Lines Tel. Co. v. Boston SafeDeposit \& Trust Co., 147 U.S. 431, 433-38 (1893).

80. See Thompson v. Hubbard, 131 U.S. 123, 131 (1889).

81. See id. ("[I]f Thompson should go out of business, or cease to prosecute the sale of the Manning book, then, unless the successor of Thompson would continue the same, Hubbard Bros. should have the exclusive right to sell said book; and that, on the execution of such contract, Thompson would assign the copyright to Hubbard Bros., and they would execute a mortgage to him on such plates, cuts, and stamps, to secure to him the performance of the contract."); Dorf v. Denton, 17 F. Supp. 531, 532-33 (S.D.N.Y. 1937) (discussing infringement action relating to the 
copyright mortgages in the recordation provision. ${ }^{82}$ Indeed, in 1834, Congress included the recordation requirement for assignments of copyright. ${ }^{83}$ If an assignment was not recorded within 60 days of the execution, it was to be "judged fraudulent and void against any subsequent purchaser or mortgagee for valuable consideration without notice." ${ }^{\prime 84}$ Also, in 1909, Congress consolidated and created the comprehensive Copyright Act. ${ }^{85}$ Under the 1909 Copyright Act, section 42 permitted copyrights to be assigned and mortgaged. ${ }^{86}$ Section 44 required that assignments of copyrights must be recorded within three months of execution in order for it to be valid against subsequent purchasers and mortgagees. ${ }^{87}$

Mortgages on copyrights became more prevalent with the arrival of technologies for new mediums of expression, copying, and distribution, especially in the area of motion pictures and television. ${ }^{88}$ Republic Pictures Corp. v. Security-First National Bank of Los Angeles provides a closer look at the practice of mortgages on copyrights in the motion picture industry. ${ }^{89}$

In that case, Pre-Em Pictures owned the story, treatment, script, continuity,

mortgage of copyrights in music compositions); Buss Mach. Works v. Watsontown Door \& Sash Co., 2 F. Supp. 758, 758 (E.D. Penn. 1933) (explaining that typically, in most chattel mortgage transactions, the mortgage would be broad and cover "all plants, factories and structures now or hereafter erected upon or attached to any of the lands which, or interest in which, are hereby conveyed or intended so to be, and all fixtures, equipment, machinery, apparatus, tools, implements and appliances, materials and supplies at present or in the future belonging thereto, whether or not the same be affixed to the freehold or be used in the operation of any of said premises or as a part of said plants or any of them, and patents, application for patents, trademarks, trade names, copyrights, formulae and the good will of the business now or hereafter carried on by the Company").

82. See Copyright Amendment, Act of June 30, 1834, 23d Cong., (1st Sess.), 4 Stat. 728. Section 205(a) (1834) ("[A]ll deeds or instruments in writing for the transfer or assignment of copyrights, being proved or acknowledged in such manner as deeds for the conveyance of land are required by law to be proved or acknowledged in the same state or district, shall and may be recorded in the office where the original copyright is deposited and recorded; and every such deed or instrument that shall in any time hereafter be made and executed, and which shall not be proved or acknowledged and recorded as aforesaid, within sixty days after its execution, shall be judged fraudulent and void against any subsequent purchaser or mortgagee for valuable consideration without notice.").

83. Id.

84. Id.

85. Copyright Act of 1909, Pub. Law 60-349, 35 Stat. 1075 (1909), available at http://www.copyright.gov/history/1909act.pdf, archived at http://perma.cc/4TA3-C9D6 (repealed in 1976).

86. $I d$.

87. Id.

88. Republic Pictures Corp. v. Security-First Nat'1 Bank of L.A., 197 F.2d 767, 771 (9th Cir. 1952).

89. Id. at 768 . 
and manuscript composition of a motion picture photoplay based on a story entitled, "A Song For Miss Julie."90 Pre-Em Pictures received certain advances from the Security-First National Bank of Los Angeles and provided the bank with the copyright in the motion picture as security for the advances. ${ }^{91}$ Later, Pre-Em Pictures defaulted on the loans and the bank sued Pre-Em Pictures in federal court to foreclose on the mortgaged copyright. ${ }^{92}$ The district court ordered the foreclosure, and the copyright was sold to the bank at public auction by the United States Marshal..$^{93}$

Republic Pictures was the distributor of the motion picture under an agreement with Pre-Em Pictures. ${ }^{94}$ Republic Pictures refused to recognize the title in the copyrights purchased by the bank at public auction. ${ }^{95}$ The bank then sued Republic Pictures for declaratory relief to determine the rights in the copyright acquired by the bank. ${ }^{96}$ The case was appealed to the Ninth Circuit. ${ }^{97}$

The Ninth Circuit held that federal courts have no jurisdiction over foreclosure of copyright mortgages even though they have subject matter jurisdiction over copyrights. ${ }^{98}$ Foreclosures on mortgaged copyrights are within the provenance of state courts and state law. ${ }^{99}$ The court indicated that it was merely following other courts' decisions on foreclosures of mortgaged patents. ${ }^{100}$

The reasoning in Republic Pictures further aided the development of intellectual property financing law. It followed federalism principles by recognizing that certain areas of law, such as copyrights and patents are within federal subject matter jurisdiction, and other areas of law, such as commercial law, are within state subject matter jurisdiction. ${ }^{101}$ The court in Republic Pictures exercised restraint as dictated by the Constitution. ${ }^{102}$ By so doing, it respected the development of secured transactions law at the state level despite the fact that the collateral property involved federally granted rights. ${ }^{103}$

\title{
C. Trademark Mortgages
}

The development of trademark mortgages began roughly the same time as

\author{
90. Id. at $771 \mathrm{n} .1$. \\ 91. Id. \\ 92. Id. \\ 93. Id. \\ 94. Id. \\ 95. Id. \\ 96. Id. \\ 97. Id. \\ 98. Id. at 770 . \\ 99. Id. \\ 100. Id. (citing Keiper v. Amico, 20 N.Y.S.2d 480, 481 (1940) (holding that federal courts \\ have no jurisdiction over foreclosure of patent mortgages)). \\ 101. Id. \\ 102. U.S. CONST. art. III $\S 2$, cl. 1. \\ 103. Republic Pictures, 197 F.2d at 770.
}


patent and copyright mortgages. ${ }^{104}$ Trademark mortgages, however, faced limitations. ${ }^{105}$ The view of courts at that time was that trademarks could not be transferred without the underlying business; therefore, trademarks could not by themselves, apart from the business, be used as security in mortgages. ${ }^{106}$ Consequently, unlike patent mortgages, where a simple recording with the Patent Office would bestow the mortgagee with rights similar to those of the patentee or grantee while the patent mortgagor continued to use the mortgaged patents in the operation of its business, ${ }^{107}$ mortgages with trademarks were more cumbersome. ${ }^{108}$

For example, in Morgan v. Rogers, J. Miller \& Sons ("Miller \& Sons") manufactured and distributed certain medicines under a specific trademark. ${ }^{109}$ The mortgagee, Morgan, made a very large loan in the amount of $\$ 48,500$ to Miller \& Sons in $1875 .{ }^{110}$ He executed a chattel mortgage to secure the debt, took possession of the property under the mortgage through agency, and operated Miller \& Sons' business of the manufacture and sale of medicines. ${ }^{111}$ Two years later, Miller \& Sons granted the defendant, Rogers, the exclusive rights to use the same trademarks to sell their medicinal compounds. ${ }^{112}$ The mortgagee brought a suit to enjoin the defendant's use of the trademarks. ${ }^{113}$

The court addressed whether the mortgagee had a mortgage in Miller \& Sons' trademarks. ${ }^{114}$ The pertinent provision in the chattel mortgage provided:

The following articles of personal property, now in our possession, and now in and upon the premises known and designated as numbers (8) eight and (12) twelve High street, in said city of Providence, viz.: The entire property, stock, furniture, and fixtures, and other articles, now in and upon said premises, together with all debts and book accounts, assets, and effects of every kind and nature, belonging to said firm of $\mathrm{J}$.

104. See Morgan v. Rogers, 19 F. 596, 597-98 (Cir. Ct. D.R.I. 1884) (Both copyright and trademark mortgages began developing in the late nineteenth century).

105. See In re Leslie-Judge Co., 272 F. 886, 887-88 (2d Cir. 1921).

106. $I d$. at 888 ("[A] further and conclusive reason for holding that the instrument does not cover the good will and trade-marks is that they are not property which can be owned in gross. They arise out of a particular business, and do not exist apart from that business. . . As the mortgage in question does not pretend to cover the company's business and franchises, it confers no lien whatever upon the good will and trade-marks. If the company could not have sold its good will and trade-marks apart from its business, it evidently could not mortgage them.”).

107. See Waterman v. Mackenzie, 138 U.S. 252, 261 (1891).

108. See Morgan, 19 F. at 597-98.

109. Id. at 596 .

110. Id. at 597.

111. Id. at 596-97.

112. Id. at 596.

113. Id.

114. Id. at 597-98. 
Miller \& Sons. ${ }^{115}$

The court found that the language was broad in its terms and covered the trademarks in the mortgage grant. ${ }^{116}$ Given that the loan was large in value at the time of the conveyance, the court stated there was no reason that Miller \& Sons' entire property was not inclusive of the trademarks for security purposes. ${ }^{117}$ Moreover, although trademarks were "an abstract right" and could not be sold apart from the associated business, trademarks may be bought and sold like other property if the underlying business was included. ${ }^{118}$ Here, the mortgagee succeeded to all of the rights in Miller \& Sons' business, took possession of the business through agency, and gained rights to "use the trade-marks, and to manufacture and sell the medicinal compounds."119 Therefore, the court declared that "[t]o hold that the trade-mark is not included in this mortgage, is to say the most valuable part of the partnership property is not covered by the words assets and effects of every kind and nature."

Because the mortgagee would only turn over the property to Miller \& Sons after they had fulfilled their obligation, the mortgage "cannot operate to divest [the mortgagee] of the exclusive right to the trade-marks if they had acquired such under the mortgage." 121 Accordingly, only the mortgagee had the exclusive right to the trademarks and the defendant had no right to use them. ${ }^{122}$

The Morgan decision demonstrated that a typical trademark mortgage at that time required the mortgagee's possession of the mortgagor's entire business associated with the trademark. ${ }^{123}$ The mortgagee employed an agent to succeed to the mortgagor's business. ${ }^{124}$ There was no recording of the trademark mortgage. ${ }^{125}$ Consequently, unlike patents, trademarks could not be easily mortgaged because the mortgagor must transfer the associated business to the mortgagee as part of the transaction, and the mortgagee must then take possession of the mortgagor's business. ${ }^{126}$

115. Id. at 597.

116. Id. ("The clause of conveyance in the mortgage is very broad in its terms.").

117. Id.

118. Id. ("There is no reason why a trade-mark cannot be conveyed with the property with which it is associated. As an abstract right, apart from the article manufactured, a trade-mark cannot be sold, the reason being that such transfer would be productive of fraud upon the public. In this respect it differs from a patent or a copyright. But in connection with the article produced, it may be bought and sold like other property. It constitutes a part of partnership assets, and is properly sold with the firm property.").

119. $I d$. at 598 .

120. Id.

121. Id.

122. Id.

123. $I d$. at 597.

124. Id. at 598 .

125. Id. at 597.

126. Id. at 598. 
Moreover, while both patent and copyright statutory provisions explicitly allowed patents ${ }^{127}$ and copyrights ${ }^{128}$ to be used in chattel mortgages, the trademark statute did not include a similar provision. ${ }^{129}$ Trademarks themselves, apart from the associated business, were excluded from mortgages. ${ }^{130}$

The rationale for the exclusion was due to the strong belief that a trademark cannot be transferred in gross without the associated business. ${ }^{131}$ For example, in Mendes v. New England Duplicating Co., the plaintiff, owner of the Paddy Company, had developed the Paddy mark in connection with the manufacturing and selling of collating machines. ${ }^{132}$ The plaintiff brought a trademark infringement claim against New England Duplicating Co. for the use of the Paddy mark in advertisements in trade periodicals. ${ }^{133}$ The defendant asserted that it had the right to use the mark, relying on the mortgage on all of the Paddy Company's assets, trademarks, and goodwill as the basis of its authority to use the Paddy trademark. ${ }^{134}$ Specifically, the defendant had entered into an agreement with a third party, Herbits, for the distribution and advertisement of collating machines to be produced by Herbits under the Paddy mark. ${ }^{135}$ "[Herbits] purported to have the right to use the Paddy name by virtue of a chattel mortgage executed by [Paddy] on all its assets and goodwill." "136 The district court stated that trademarks and goodwill are "species of property [that] cannot be owned in gross and therefore cannot be sold or transferred apart from the franchise and the business of the company." 137 Therefore, the mortgage on the trademarks themselves was held invalid. ${ }^{138}$

The court in Mendes strictly followed an earlier case, In re Leslie-Judge Co., decided by the Second Circuit in 1921. ${ }^{139}$ The relevant provision for property

127. 35 U.S.C. $§ 261$ (2014) (“[A]n assignment, grant, or conveyance shall be void as against any subsequent purchaser or mortgagee for a valuable consideration, without notice, unless it is recorded in the Patent and Trademark Office within three months from its date or prior to the date of such subsequent purchase or mortgage.").

128. Copyright Act, 17 U.S.C. $§ 101$ (2014) (defining "transfer of copyright ownership" as "an assignment, mortgage, exclusive license, or any other conveyance, alienation, or hypothecation of a copyright or of any of the exclusive rights comprised in a copyright, whether or not it is limited in time or place of effect, but not including a nonexclusive license.").

129. See In re Leslie-Judge Co., 272 F. 886, 888 (2nd Cir. 1921) (discussing the absence of trademark statutory provisions for mortgages on trademarks).

130. Id.

131. Id.

132. Mendes v. New England Duplicating Co., 94 F. Supp. 558, 559 (D. Mass. 1950).

133. Id.

134. Id. at 561 .

135. Id. at 560 .

136. Id.

137. Id. at 561 .

138. Id. (holding that the chattel mortgage did not and could not convey any trade-mark rights of the Paddy Machine Company).

139. See In re Leslie-Judge Co. 272 F. 886 (2d Cir. 1921). 
covered by the mortgage transaction in that case stated:

All goods and chattels wherever situated, including plant, machinery, equipment, supplies of all kinds, furniture, and all personal and other property, property rights, good will, copyrights, trade-marks, and choses in action of every kind whatsoever, as now owned or which may hereafter be acquired or owned by the company, and also all the estate, right, title, interest, property, possession, income, and demand whatsoever, as well in law as in equity of the company, to have and to hold the same and every part thereof. ${ }^{140}$

The mortgagor later filed for bankruptcy. ${ }^{141}$ The district court ordered the bank's property to be sold free of the mortgage that the mortgagor company had signed on August 1, 1909, to the Title Guarantee \& Trust Company to secure an amount of $\$ 700,000 .{ }^{142}$ The Second Circuit affirmed the district court's decision because mortgages on trademarks were not permissible due to the fact that trademarks "are not property which can be owned in gross," as "[t]hey arise out of a particular business, and do not exist apart from that business." the company could not have sold its good will and trade-marks apart from its business, it evidently could not mortgage them."144

The early prohibition of trademark mortgages began to dissipate as courts adopted a modern view of goodwill and allowed transfers and assignments of trademarks apart from the business. ${ }^{145}$ For example, in Glamorene Products Corp. v. Procter \& Gamble Co., Stauffer Chemical Company assigned the mark "BOUNCE" for dry-cleaning detergent to Procter \& Gamble. ${ }^{146}$ The grant recited that the assignment was together with the goodwill of the business. ${ }^{147}$ There was no transfer of the associated business as Stauffer continued to operate and retain the tangible assets of the business. ${ }^{148}$ Upon receiving the assignment, Procter \& Gamble used the mark on its own dry-cleaning detergent. ${ }^{149}$ The court found the assignment valid; the trademarks along with attached goodwill can be assigned

140. Id. at 887 .

141. Id.

142. Id.

143. Id. at 888; see also President Suspender Co. v. MacWilliam, 238 F. 159, 162 (2d Cir. 1916) ("A trade-mark right cannot exist independently of some business in which it is used. The sole function of a trade-mark being to indicate the origin or ownership of the goods, it cannot exist apart from the business to which its use is incident. There is no such right known to the law as an exclusive ownership in a trade-mark apart from the right to use it in a business. It cannot exist as a right in gross.").

144. In re Leslie-Judge, $272 \mathrm{~F}$. at 888 .

145. See Glamorene Prods. Corp. v. Procter \& Gamble Co., 538 F.2d 894, 895 (C.C.P.A. 1976); see also Money Store v. Harriscorp Fin. Inc., 689 F.2d 666, 678 (7th Cir. 1982).

146. Glamorene Prods., 538 F.2d at 895.

147. Id.

148. Id.

149. Id. 
separately from the business. ${ }^{150}$ Consequently, trademarks and their attached goodwill can also be used as security in mortgages without the associated business. $^{151}$

\section{MOVING From IP MORTGAGE TO SECURED TRANSACTIONS}

From the end of World War II to 1970, the United States experienced significant economic growth. ${ }^{152}$ Not surprisingly, the nation also embarked on major changes in the law in order to facilitate the postwar boom. ${ }^{153}$ The Uniform Commercial Code was promulgated in 1952 in an effort to bring uniformity to commercial law across the states and to facilitate and increase daily transactions in commerce. ${ }^{154}$ In 1962, with the promulgation of the Official Text of Article 9 of the Uniform Commercial Code ("UCC-9"), modern financing law was born. ${ }^{155}$ Article 9 eliminated antiquated distinctions among security devices, including mortgages, pledges, conditional sales, factor, warehousing and others, with a

150. Id.

151. Id. at 895-96 (stating that "transfer of tangible assets (inventory, labels, customer lists, formulas, etc.) is not necessary to an effective trademark assignment") (citing Sterling Brewers, Inc. v. Schenley Indus., Inc., 441 F.2d 675 (C.C.P.A. 1971); Hy-Cross Hatchery, Inc. v. Osborne, 303 F.2d 947 (C.C.P.A. 1962)). Moreover, the liberal trends relating to trademark assignments without the transfer of tangible assets spill over to the area of trademark licensing. Xuan-Thao Nguyen, Bankrupting Trademarks, 37 U.C. DAVIS L. REV. 1267, 1281 (2004) (stating that courts have relaxed the requirement on quality control and allowed trademark owners to satisfy the quality control requirement by choosing various means for indirect and direct control without fear of trademark abandonment).

152. See, e.g., Charles Geisst, The Last Partnerships: Inside the Great Wall Street MONEY DYNASTIES 274-85 (2002) (describing the economic growth in the 1950s and 1960s). The economic growth in the post-war years also impacted real estate transactions, as more people moved to suburban houses. See Nicole Stelle Garnett, Suburbs as Exits, Suburbs as Entrance, 106 MiCH. L. REV. 277, 282 (2007) (stating that the "postwar economic boom enabled more people than ever before to choose a suburban life").

153. See Miek Berends, An Elusive Profession? Lawyers in Society, 26 LAW \& Soc'y REV. 161, 181 (1992) (stating that the "postwar economic boom and the resulting economic and legal expansion led to dramatic changes in the scale of markets, industries, commerce, and economic relations. These increased the market for legal work as did the growth of welfare states, their subsequent expansion of legislation, and the need for legal services").

154. Robert Braucher, Uniform Commercial Code-Documents of Title, 102 U. PA. L. REV. 831, 831 (1954) (indicating that Article 7 of the UCC "deals comprehensively with documents of title; it is designed to replace the Uniform Warehouse Receipts Act, the Uniform Bills of Lading Act, and sections 27-40 of the Uniform Sales Act").

155. Although the UCC was promulgated in 1952, the official text of Article 9 became official in 1962 for states to adopt. Donald W. Baker, The Ambiguous Notification Requirement of Revised UCC Section 9-312(3): Inventory Financers Beware!, 98 BANKING L. J. 4 , 4 (1981) (noting that the 1962 official text of Article 9 "was in force in every state except one"). 
unitary system of secured transaction law. ${ }^{156}$ The unitary system covers all transactions, regardless of form, that create security interests in personal property (that is, property other than real estate). ${ }^{157}$ Prior to the adoption of UCC-9, there was no single body of law that governed liens in personal property. ${ }^{158}$ Each state had its own statutes and common law doctrines governing liens. ${ }^{159}$ There was no uniformity across the United States. ${ }^{160}$ Article 9's unitary system has been an enormous success and a crowning achievement for the National Conference of Commissioners on Uniform State Laws ("NCCUSL") as all states have adopted it. ${ }^{161}$

The success of UCC-9 meant a reduction in transaction costs caused by overlapping, opaque, and confusing security devices. ${ }^{162}$ The success of the law meant the proliferation of secured transactions in the United States. ${ }^{163}$ It also meant an increase in financing using all different types of intellectual property, including patents, copyrights and trademarks - increasingly valuable assets for a company in modern time. ${ }^{164}$ Consequently, gone was the conditional

156. Appeal of Copeland, 531 F.2d 1195, 1203 (3d Cir. 1976) (noting that "Article 9 simplifies pre-Code secured financing by providing for the unitary treatment of all security arrangements. It eliminates many of the antiquated distinctions between various security devices in favor of a single security interest, $\S \S 9-102,1-201(37)$, and a single set of rules regarding creation and perfection, designed to govern any transaction (regardless of its form) which is intended to create a security interest in personal property or fixtures."); see also Eric J. Pullen, Revised Article 9 of the Uniform Commercial Code and Agricultural Liens in Texas, 40 TEX. J. BuS. LAW 1, 8 (2004) (providing a brief history of Article 9 and how it supplanted antiquated security devices of pledges, chattel mortgages, conditional sales, trust receipts and others with a single standardized security device).

157. See U.C.C. § 9-109 (2014).

158. Pullen, supra note 156 , at 8.

159. Id. at 9 .

160. Id. (noting that Article 9 "explicitly superseded all previous legislation, which had up to that point been a morass of security devices that had piled up over the years, in the states where it was adopted. With the implementation of Article 9, a state would now have a single, comprehensive system for the regulation of security interests in personal property.").

161. Id. ("Article 9 was adopted by almost every state with minimal modification by the end of the 1960s.").

162. Levitin, supra note 15, at 695 ("By avoiding demonstrative formalities, Article 9 reduces the transaction costs involved in securitizing mortgages."); Charles W. Mooney, Jr., The Mystery and Myth of 'Ostensible Ownership' and Article 9 Filing: A Critique of Proposals to Extend Filing Requirements to Leases, 39 ALA. L. REV. 683, 745-52 (1988) (discussing the benefits of UCC-9 system, including veracity of filing information, priority order, and reduction of discovery cost).

163. Steven L. Harris \& Charles W. Mooney, Jr., How Successful Was the Revision of UCC Article 9?: Reflections of the Reporters, 74 CHI.-KENT L. REV. 1357, 1397 (1999) (“[T] he very success of Article 9 has resulted in a substantial increase in the sophistication of secured transactions since the early years of the UCC."').

164. See generally Xuan-Thao Nguyen, Collateralizing Intellectual Property, 42 GA. L. REV. 1, 16 (2007) (discussing the use of intellectual property assets as collateral in financing). 
assignment of patents and copyrights. ${ }^{165}$ The cumbersome practices discussed in Waterman v. Mackenzie were no longer necessary; ${ }^{166}$ the secured party or lender need not demand assignments of patents or copyrights upfront with subsequent return of the patents or copyrights to the borrower upon satisfaction of the payment obligations. ${ }^{167}$ Likewise, the practice of appointing an agent to take over the possession of the borrower's business for purposes of trademark mortgages became impractical and unnecessary. ${ }^{168}$ Under modern UCC-9 law, the borrower or debtor continues to own and use the intellectual or other personal property for the business operation. ${ }^{169}$ In doing so, the debtor would be able to make payments to the secured party. ${ }^{170}$ There was no need for the secured party to have assignment either directly or via an agent. ${ }^{171}$ UCC-9 law protects the secured party's interest without the antiquated, cumbersome practices. ${ }^{172}$

During a period of major change in state commercial law across the nation, Congress overhauled trademark law in 1946, patent law in 1952, and copyright law in $1976 .{ }^{173}$ These historic milestones brought intellectual property law to modern time, recognizing the significant role of intellectual property in the economy.

Soon, modern UCC-9 law intersected with modern intellectual property law, raising new questions that required courts to address intellectual property issues within the spirit of UCC-9's functional approach. ${ }^{174}$ Because UCC-9 is a creature

165. Weinberg \& Woodward, supra note 16, at 65-66 ("Although pre-U.C.C. law was in some respects similar to the traditional methods for employing patents and trademarks as collateral, Article 9 changed the very vocabulary of secured lending. For example, no longer would one get security from a 'chattel mortgage' or 'conditional sale'; 'security interest' became the term to embrace all forms of secured lending on personal property.").

166. See supra Part I.A.

167. In re Cybernetic Servs., Inc., 239 B.R. 917, 920-21 (B.A.P. 9th Cir. 1999) ("The UCC created a single security device, which was not dependent on who had title to the property. [Article 9] applies to secured transactions involving personal property regardless of 'whether title to collateral is in the secured party or in the debtor.' Because transferring title no longer has significance in creating a security interest in personal property, most security interests created after adoption of the UCC do not involve the transfer of title.") (citations omitted).

168. Weinberg \& Woodward, supra note 16, at 65-66 (explaining how UCC-9's new approach differs from the traditional conditional assignments of intellectual property).

169. Id. at 66 (noting that under UCC-9 "the location of title is immaterial").

170. Id. at 122 .

171. Id. at 65-66.

172. Id.

173. Congress enacted the Lanham Act in 1946, the Patent Act in 1952, and the Copyright Act in 1976. Robert P. Merges Et Al., Intellectual Property IN THE NeW TeChNOLOGiCAl Age 127, 433, 764 (Walters Kluwer Law \& Business eds., 6th ed. 2012).

174. Weinberg \& Woodward, supra note 16, at 62-64. ("Uncertainty and confusion probably always have existed about the employment of intellectual property as collateral for a loan. Since the drafting of Article 9 of the Uniform Commercial Code, an uneasy coexistence of state and federal law has developed. Both state and federal law now arguably apply when a debtor attempts 
of state law, questions arose related to the manner to perfect the security interests in patents, copyrights and trademarks as collateral. ${ }^{175}$ Specifically, the question arose as to whether federal or state recording regimes would be applicable to govern security interests in intellectual property. ${ }^{176}$ These questions have direct impact on the secured party's rights against other secured parties, lenders, and third parties. ${ }^{177}$ How courts addressed these questions would either encourage or hinder access to credit for businesses and individuals with intellectual property as collateral.

\section{A. A New Approach to Perfection of Patents Collateral}

In Waterman v. Mackenzie, the United States Supreme Court enunciated that patent conditional assignments or mortgages recorded with the Patent Office have the equivalent of possession of the patents. ${ }^{178}$ The practice to protect security interests in patents at that time was to file the conditional assignment or mortgages with the Patent Office. ${ }^{179}$ Financing practices, however, have changed substantially in modern time.

In modern time, the grant of a security interest in personal property, including patents, is understood as not an outright transfer of ownership in the property. ${ }^{180}$ Secured financing no longer requires title or ownership of the collateral property. ${ }^{181}$ Indeed, Article 9 of the Uniform Commercial Code comment to section 9-101 provides:

This article does not determine whether "title" to the collateral is in the secured party or in the debtor and adopts neither a "title theory" nor a "lien theory" of security interests. Rights, obligations and remedies under the Article do not depend on a location of title. ${ }^{182}$

Several courts, which understood that the functional approach to modern financing law was that the grant of a security interest would not effectuate a transfer of present ownership in the patent, held that such a grant is not required to be recorded with the Patent Office. ${ }^{183}$ The Patent Office's filing system is for

to use a patent or trademark to secure a loan. The extent to which each body of law is applicable and the interaction between the two systems was left unclear by the drafters of Article 9 and has not been clarified by Congress. The radical differences between the state and federal systems, both conceptually and as implemented, further complicate the uncertainty in the law.").

175. Id.

176. Id. at 73-74.

177. Id. at 65-67.

178. Waterman v. Mackenzie138 U.S. 252, 260-61 (1891).

179. Id. at 260 .

180. See U.C.C. § 9-202 (2014).

181. Id. (stating that "the provisions of this article with regard to rights and obligations apply whether title to collateral is in the secured party or the debtor").

182. U.C.C. § 9-101 cmt. 9 (1973).

183. See, e.g., In re Cybernetic Servs., Inc., 239 B.R. 917, 920 (B.A.P. 9th Cir. 1999); City 
assignments or transfer of titles. ${ }^{184}$

For example, in City Bank \& Trust Co. v. Otto Fabric, Inc., the bank provided loans to Otto Fabric and received a security interest in "all contract rights, receivables and general intangibles" in 1983. ${ }^{185}$ The bank immediately filed a financing statement with the Secretary of State in Kansas. ${ }^{186}$ Two years later Otto Fabric and the bank signed a new security agreement wherein the debtor provided to the bank security interest in several assets, including three patents. ${ }^{187}$ As part of the secured transaction, the debtor promised to assign the patents for collateral purposes. ${ }^{188}$ The bank recorded the financing statement with the Secretary of State in Kansas in early January 1985 and filed the patent assignments with the Patent Office a few days later. ${ }^{189}$ In April 1985, the debtor filed for bankruptcy, and the trustee sought to set aside the bank's security interest in the patents because the assignment was filed outside the ninety day preference period. ${ }^{190}$ The bankruptcy court granted the bank relief on the other assets, except the three patents serving as collateral, because the bank timely perfected the security interest in the other assets within the ninety day preference period. ${ }^{191}$ The bank appealed. ${ }^{192}$

The district court reversed the bankruptcy court's decision. ${ }^{193}$ The court noted that the relevant federal patent statutory provision does not completely preempt the recording of a security interest in patents. ${ }^{194}$ Specifically, the statute does not expressly require the filing of an assignment with the Patent and Trademark Office in order to perfect a security interest in patents. ${ }^{195}$ Also, the court observed Congress has amended patent law numerous times "since the advent of modern commercial law" but chose not to completely preempt the field of filing. ${ }^{196}$

Most importantly, the Court observed that if the filing requirement with the Patent Office exists, "which is considered an absolute assignment," it would

Bank \& Trust Co. v. Otto Fabric, Inc., 83 B.R. 780, 782-83 (D. Kan. 1988).

184. In re Cybernetic, 239 B.R. at 920; Otto Fabric, 83 B.R. at 782.

185. Otto Fabric, 83 B.R. at 780.

186. Id.

187. Id.

188. Id.

189. Id. at 781 .

190. Id.

191. Id.

192. $I d$.

193. Id. at 782 .

194. Id. ("[W]hile the federal statute may preempt in part the system for perfecting security interests in patents, it is only a partial preemption. It leaves open a state filing to protect one's security interest in a patent against a lien creditor.").

195. Id. ("[T]he federal statute does not expressly state that one must file an assignment with the Patent and Trademark Office to perfect a security interest.").

196. Id. ("The [patent] statute has been amended since the advent of modern commercial law. If Congress intended to preempt the field of filing, it could have said so."). 
reduce the financing with patents as collateral. ${ }^{197}$ For example, the court provided, "a patentee or his assigns could not grant a license after using the patent as collateral for a loan if the secured lender filed the security agreement with the Patent Office." 198 The only way for the patentee to be able to license to others is to request permission from the lender. ${ }^{199}$ Also, without the rights to the patent after the assignment, the only way the patentee could bring a lawsuit is to join the lender as an indispensable party. ${ }^{200}$ In summary, the court asserted that the desire to impose a rule for a federal, central filing system of patent collateral will not be rational, convenient, or consistent with modern financing and Article 9 of the Uniform Commercial Code. ${ }^{201}$ That means the single, federal system will diminish financing with patents as collateral. ${ }^{202}$ Therefore, City Bank \& Trust Co. indeed had perfected its security interest in the patents within the ninety days preference, like the other collateral in the transaction. ${ }^{203}$

\section{B. New Approaches to Copyright Collateral}

The growth in the entertainment and software industries spurred financing for the creation and distribution of new content. ${ }^{204}$ A number of court cases focused on the perfection of security interests in copyrights of films in these industries, forcing a close examination of whether federal law or state law governs when the secured creditors file the security interest in copyrights. ${ }^{205}$ The filing question is significantly important. ${ }^{206}$ Filing in the wrong office renders the security interest

197. Id. at 783 .

198. Id.

199. Id.

200. $I d$.

201. Id. at 780 .

202. Id.

203. In later years, courts continued to rule that perfection of security in patents collateral is with UCC-9. See, e.g., In re Cybernetic Servs., Inc., 239 B.R. 917, 920 (B.A.P. 9th Cir. 1999).

204. Banks have been providing financing in the movie industry since the 1920's. See Anousha Sakoui, Star-Struck Bankers Return to Hollywood to Finance Movies, BLOOMBERG(June 19, 2014), http://www.bloomberg.com/news/2014-06-19/star-struck-bankers-return-to-hollywoodto-finance-movies.html, archived at http://perma.cc/LJ6J-FUSX (reporting that JPMorgan has been working with the studios since the 1920s).

205. See, e.g., Paul A. Baumgarten, Copyrights as Collateral: Perfection Finally Perfected After Peregrine?, 71 U. DET. MERCY L. REV. 581 (1994); Lorin Brennan, Financing Intellectual Property Under Federal Law: A National Imperative, 23 Hastings COMM. \& ENT. L.J. 195 (2001); Gary O. Concoff, Motion Picture Secured Transactions under the Uniform Commercial Code: Problems in Perfection, 13 UCLA L. REV. 1214 (1966); Steven Weinberger, Note, Perfection of Security Interest in Copyrights: The Peregrine Effect on the Orion Pictures Plan of Reorganization, 11 CARDOZO ARTS \& ENT. L.J. 959 (1993).

206. See Justin M. Vogel, Note, Perfecting Security Interests in Unregistered Copyrights: Preemption of the Federal Copyright Act and How Filing in Accordance with Article 9 Leads to the Creation of a Bankruptcy "Force Play," 10 Am. BANKr. InST. L. REV. 463, 466 (2002) 
unperfected, losing priority to other creditors. ${ }^{207}$ In other words, the secured creditor without proper perfection cannot recover on the money loaned to the borrower; other creditors would get paid first from the pool that is already small due to the borrower's dire financial condition. ${ }^{208}$

A line of court decisions on perfection of copyright collateral began with the controversial decision In re Peregrine Entertainment, Ltd. ${ }^{209}$ In that case, National Peregrine, Inc. ("NPI") filed for bankruptcy under Chapter 11 in $1989 .{ }^{210}$ Prior to the bankruptcy filing, NPI was in the entertainment industry, developing and distributing television programs. ${ }^{211}$ NPI's principal assets consisted primarily of copyrights, distribution rights and licenses of films, and account receivables arising from the licensing of the films. ${ }^{212}$ To obtain financing for its business, NPI's predecessor by merger entered into a credit line agreement with Capitol Federal Savings and Loan Association of Denver ("Cap Fed") for $\$ 6,000,000$ in June $1985 .{ }^{213}$ The credit was secured by NPI's assets, including "[a]ll inventory consisting of films and all accounts, contract rights, chattel paper, general intangibles, instruments, equipment, and documents related to such inventory, now owned or hereafter acquired by the Debtor." 214

Cap Fed filed its UCC-1 financing statement in California, Colorado, and Utah to perfect its security interest in NPI's assets. ${ }^{215}$ It did not file with the United States Copyright Office with respect to the copyrights. ${ }^{216}$

As debtor-in-possession under Chapter 11, NPI filed a complaint against Cap Fed, asserting that the bank failed to file its security interest in the copyrights and the account receivables generated by the licensing and distribution of the films with the Copyright Office. ${ }^{217}$ Due to the bank's lack of perfection of the security interest, NPI claimed that it enjoyed a judicial lien on the copyrights and account receivables thereunder. ${ }^{218}$ The bankruptcy court held for Cap Fed, and NPI appealed to the district court. ${ }^{219}$ Kozinski, Circuit Judge, sitting by designation, reversed. ${ }^{220}$ The judge cited to the federal copyright policy for a central, uniform system of recording security interests in copyrights and held that Cap Fed's filing

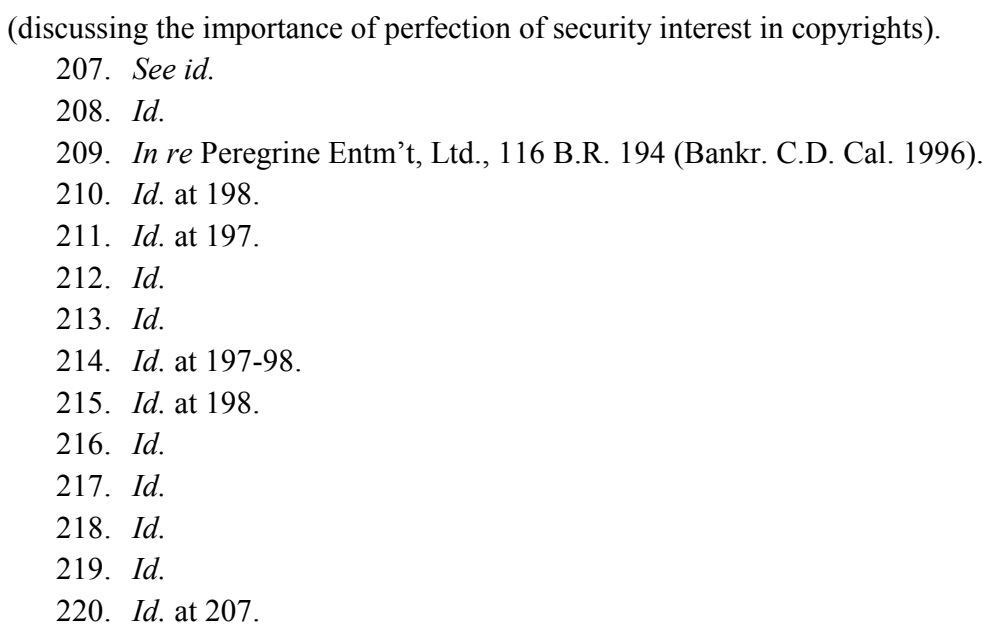


in the states' offices failed to provide notice to third parties. ${ }^{221}$ Accordingly, NPI, as debtor-in-possession, avoided Cap Fed's unperfected security interest. ${ }^{22}$

The National Peregrine decision was controversial because the security interest in that case included intangibles related to copyrights, which both commentators and courts called into doubt. ${ }^{223}$ Subsequent decisions, however, narrowed and modified the National Peregrine holding. ${ }^{224}$

The court in National Peregrine did not distinguish between registered copyrights and unregistered copyrights. ${ }^{225}$ The majority of copyrights are not registered with the United States Copyright Office. ${ }^{226}$ That does not mean that the unregistered copyrights are not protected under federal copyright law. ${ }^{227}$ Copyright protections begin at the time of completion, regardless of registration, ${ }^{228}$ and it is not practical to require authors to register all works of authorship. ${ }^{229}$ Consequently, copyright owners do not feel the need to register their copyrights, as they are still able to exploit their copyrights and use them as collateral in secured transactions. ${ }^{230}$

In Aerocon Engineering Inc. v. Silicon Valley Bank (also known as In re World Auxiliary Power Co.), the debtors borrowed money from Silicon Valley

221. Id. at 201-02.

222. Id. at 207.

223. See In re World Auxiliary Power Co., 303 F.3d 1120, 1131 (9th Cir. 2002); MCEG Sterling, Inc. v. Phillips Nizer Benjamin Krim \& Ballon Eyeglasses, 646 N.Y.S.2d 778, 780 (N.Y. Sup. Ct. 1996); In re Together Dev. Corp., 227 B.R. 439, 441 (Bankr. D. Mass. 1998); Schuyler M. Moore, "Entertainment Bankruptcies: The Copyright Act Meets the Bankruptcy Code," 48 BuS. LAW. 567, 571-72 (1993) (stating that the holding in National Peregrine was "somewhat questionable because the assets in question were not themselves copyrights. A license and related receivable seem analogous to an installment note for the sale of land. Security interests in such installment notes are perfected under the U.C.C., not under real property recording statutes").

224. See In re World Auxiliary, 303 F.3d at 1131; In re World Auxiliary Power Co., 244 B.R. 149, 253-56 (Bankr. N.D. Cal. 1999).

225. See In re World Auxiliary, 303 F.3d at 1129 (noting that the Peregrine court did not specify that the copyrights for collateral were registered or unregistered).

226. Id. at 1131 (stating that the Copyright Act contemplates that most copyrights will not be registered).

227. Id.

228. Id. (noting that the Copyright Act provides "copyrights 'may' be registered, implying that they don't have to be, and since a fee is charged and time and effort is required, the statute sets up a regime in which most copyrights won't ever be registered") (citations omitted). Typically, registration is necessary for litigation and remedies purposes. 17 U.S.C. § 411(a) (2014).

229. See id. ("Since copyright is created every time people set pen to paper, or fingers to keyboard, and affix their thoughts in a tangible medium, writers, artists, computer programmers, and web designers would have to have their hands tied down to keep them from creating unregistered copyrights all day every day.").

230. Id. (noting that the Copyright Act contemplates that most copyrights will not be registered); see also 17 U.S.C. § 208(a) (2014) (permitting, but not requiring, registrations of copyrights). 
Bank and signed a security agreement to secure the loan. ${ }^{231}$ The security agreement granted the bank a security interest in copyrights embodied in drawings, blueprints, and computer software. ${ }^{232}$ The debtors did not register their copyrights with the Copyright Office. ${ }^{233}$ The bank then filed a UCC-1 financing statement with the Secretary of State of California where the debtors were located. ${ }^{234}$ Thereafter, the debtors filed for bankruptcy, and the bankruptcy court approved the trustee's sale of the bankruptcy estate's assets, including the copyrights and the trustee's avoidance power to Aerocon Engineering. ${ }^{235}$ Aerocon brought an action against the bank, seeking to avoid the security interest of the bank in the copyrights. ${ }^{236}$ The bankruptcy court ruled for the bank. ${ }^{237}$ Aerocon appealed to the Ninth Circuit. ${ }^{238}$

The Ninth Circuit distinguished National Peregrine ${ }^{239}$ and rejected two other lower court's decisions that had extended National Peregrine's holding to perfection of security interest in unregistered copyrights ${ }^{240}$ for several reasons. ${ }^{241}$ National Peregrine and subsequent decisions concerned only the manner of perfection of security interest in copyrights; they did not address unregistered copyrights. ${ }^{24}$ Also, the Copyright Office's recordation system is only for registered copyrights; none is available for unregistered copyrights. ${ }^{243}$ Moreover, the Copyright Act contains no express provision prohibiting a secured party from perfecting its security interest in unregistered copyrights under the state law system. $^{244}$ Therefore, the court held that there was no federal preemption of perfection of security interests in unregistered copyrights. ${ }^{245}$

Consequently, if a copyright is registered, the recording of a security interest in the registered copyright is with the Copyright Office. ${ }^{246}$ If the copyright is unregistered, UCC-9 filing system applies. ${ }^{247}$ Most importantly, the court warned

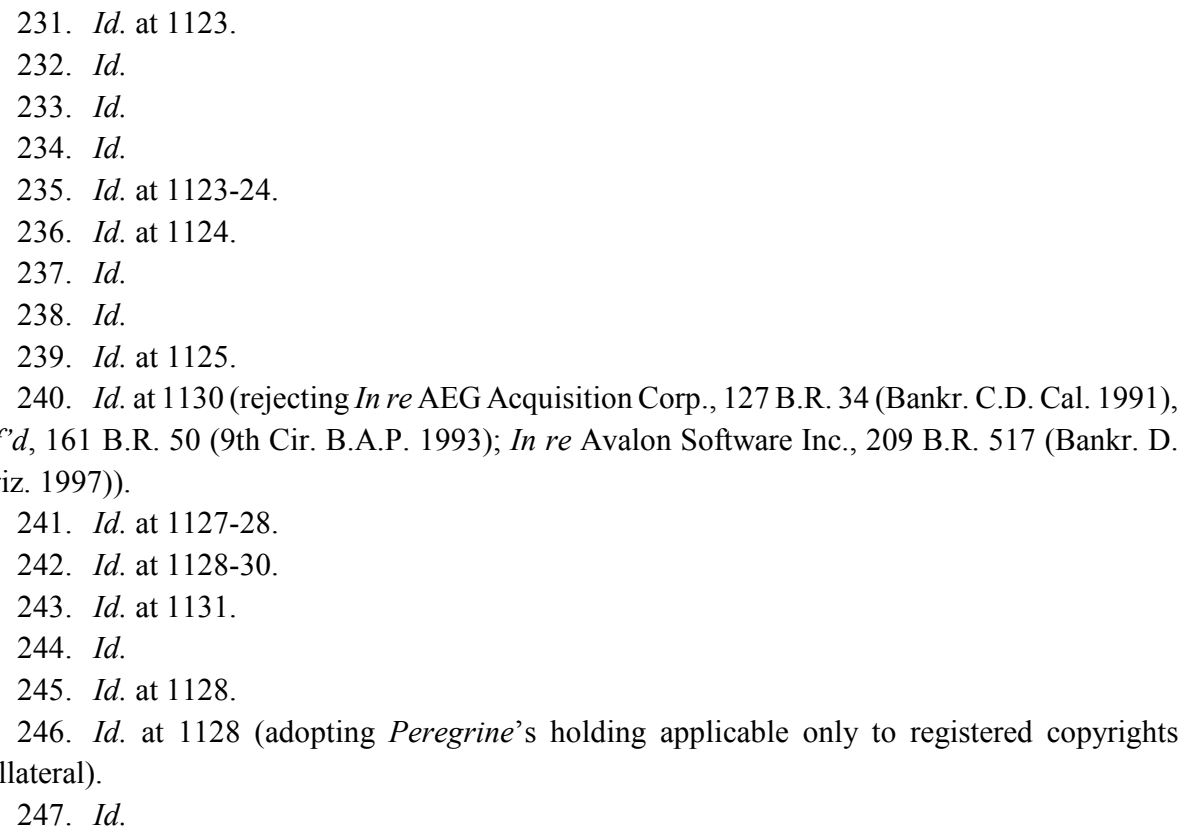


that without an approach for perfecting security interests in unregistered copyrights, "no lender would lend against unregistered copyrights if they couldn't perfect their security interest." 248 Unregistered copyrights "have value as collateral," but without a system to perfect their security interest "they would have no value at all."249

The Ninth Circuit also noted that the boom in the software industry means that more copyrights in software will be used as collateral and after-acquired collateral in secured transactions. ${ }^{250}$ Imposing the burden of registration for copyrights before they can be used as collateral in financing would cause a heavy burden on software developers:

If software developers had to register copyrights in their software before using it as collateral, the last half hour of the day for a software company would be spent preparing and mailing utterly pointless forms to the Copyright Office to register and record security interests. Our reading of the law "promote[s] the Progress of Science and useful Arts" by preserving the collateral value of unregistered copyrights, which is to say, the vast majority of copyrights. ${ }^{251}$

Accordingly, the court affirmed the lower court's decision in favor of Silicon Valley Bank. ${ }^{252}$

In summary, the cases discussed above allow both registered and unregistered copyrights to serve as collateral in financing. ${ }^{253}$ The courts recognized the growth in a new medium of copyrights, particularly software copyrights, and refined its approaches to ensure the ease of financing for both existing and new creative content industries. ${ }^{254}$

\section{A New Approach to Trademarks Collateral}

Modern commercial law, especially Article 9 of the Uniform Commercial Code in which old security devices were replaced with a simple and unified structure for secured transactions in order to encourage secured financing across the United States, has an impact on the use of trademarks as collateral in financing. ${ }^{255}$ Also, as courts adopted modern trends in permitting the assignments of trademarks without the underlying business, trademarks can be transferred separately. ${ }^{256}$ These new developments opened the door for trademarks to be

248. Id. at 1132 .

249. Id.

250. $I d$.

251. $I d$.

252. Id.

253. In re Peregrine Entm't, Ltd., 116 B.R. 194, 207 (Bankr. C.D. Cal. 1996); World Auxiliary, 303 F.3d at 1128.

254. In re Peregrine, 116 B.R. at 207; World Auxiliary, 303 F.3d at 1128.

255. See Harris \& Mooney, supra note 163, at 1397; Pullen, supra note 156, at 9.

256. See Glamorene Prods. Corp. v. Procter \& Gamble Co., 538 F.2d 894, 895-96 (C.C.P.A. 
used as collateral in financing. ${ }^{257}$ Soon, cases involving security interests in trademarks reached the court. ${ }^{258}$

The first case that addressed the perfection of trademark collateral was In re Roman Cleanser Co. ${ }^{259}$ The Roman Cleanser Company, a Michigan corporation, was in the business of manufacturing, packaging and marketing household cleaning products under the trademark "Roman" and other marks. ${ }^{260}$ All of the marks were federally registered. ${ }^{261}$ Roman then filed for bankruptcy. ${ }^{262}$ The bankruptcy trustee sold the federally registered trademarks, formulas, and customer lists to Michlin Chemical Corporation for $\$ 180,000{ }^{263}$ After the sale, National Acceptance Company of America ("NAC") sought to intervene, claiming that it had senior, perfected security interest in the trademarks. ${ }^{264}$ The facts revealed that a few years before bankruptcy, Roman granted NAC a security interest "in and to all of Roman Cleanser's then owned and thereafter acquired goods, equipment, and general intangibles and the proceeds thereof as collateral for the payment of all indebtedness and liabilities then existing or thereafter arising of Roman Cleanser to NAC." ${ }^{265}$ This grant was part of a loan and security agreement. $^{266}$ NAC timely filed a financing statement with the Michigan Secretary of State. ${ }^{267}$ The trustee opposed on the ground that NAC did not file a conditional assignment of the federally registered trademark with the United States Patent and Trademark Office and that NAC's security interest was therefore unperfected. ${ }^{268}$

The bankruptcy court held for NAC. ${ }^{269}$ The court distinguished an assignment from a security interest of a trademark. ${ }^{270}$ On the one hand, an assignment means absolute transfer of all right, title and interest to the trademark, whereas a security interest is not. ${ }^{271}$ Indeed, on the other hand, a security interest is "merely what the term suggests - a device to secure an indebtedness ... [i]t is a mere agreement to assign in the event of a default by the debtor."272

1976); see also Money Store v. Harriscorp Fin. Inc., 689 F.2d 666, 678 (7th Cir. 1982).

257. See generally In re Roman Cleanser, 802 F.2d 207 (6th Cir. 1986) (discussing trademarks used as collateral in financing).

258. See id.

259. Id.

260. Id. at 208 .

261. Id.

262. Id.

263. Id.

264. Id.

265. Id.

266. Id.

267. Id.

268. Id. at 210 .

269. Id. at 208.

270. $I d$.

271. Id. at 210 .

272. Id. (Thomas, J., concurring) (alteration in original) (quoting the Bankruptcy Court's 
Consequently, a promise to assign a trademark is not an absolute transfer of the trademark covered by the federal trademark law. ${ }^{273}$ Federal trademark law governs the transfers of trademarks and requires filing such transfers. ${ }^{274}$ State law, not federal trademark law, governs the manner of perfecting a security interest in trademarks. ${ }^{275}$

In the original bankruptcy proceedings, the court also noted that if Congress intended to provide "a means for recording security interests in trademarks in addition to assignments, it would have been simple to so state." 276 Moreover, the court reasoned that a federal, central filing for all security interests in trademarks would not further Congress' concern in passing the federal Lanham Act trademark law for protecting the public from the deceptive use of trademarks because a secured creditor with only a security interest in the trademark collateral does not have the right to use the trademark absent debtor default on the loan. ${ }^{277}$ The Sixth Circuit subsequently affirmed the lower court's decision. ${ }^{278}$

Subsequent cases have adopted both "the logic and holding" of the Roman Cleanser court. ${ }^{279}$ Some courts offered strong public policy reasons for how a federal filing system under the Lanham Act for security interests in trademarks would not encourage financing. ${ }^{280}$

\section{U.S. SMALl BUSINESS ADMINISTRATION AND IP MORTGAGES}

Following the Waterman v. Mackenzie $e^{281}$ decision, intellectual property mortgages began to flourish, which was evidenced by the fact that not only private creditors, but the United States Small Business Administration ("SBA") provided loans secured by intellectual property. ${ }^{282}$ In 1953, Congress passed the Small Business Act to create SBA whose function was to "aid, counsel, assist and protect, insofar as is possible, the interest of small business concerns." 283 SBA

observation).

273. Id.

274. Id. at 212 .

275. In re Roman Cleanser Co., 43 B.R. 940, 946 (Bankr. E.D. Mich. 1984).

276. Id.

277. $I d$.

278. In re Roman, 802 F.2d at 208.

279. See Trimarchi v. Together Dev. Corp., 255 B.R. 606, 611-12 (Bankr. D. Mass. 2000) (noting cases).

280. See id.; In re TR-3 Industries, 41 B.R. 128, 131 (Bankr. C.D. Cal. 1984); In re C.C. \& Co., Inc., 86 B.R. 485, 487 (Bankr. E.D. Va. 1988); In re Chattanooga Choo-Choo Co., 98 B.R. 792, 795-96 (Bankr. E.D. Tenn. 1989); In re 199Z, Inc., 137 B.R. 778, $781-82$ (Bankr. C.D. Cal. 1992).

281. Waterman v. Mackenzie, 138 U.S. 334 (1891).

282. See Brian W. Jacobs, Using Intellectual Property to Secure Financing after the Worst Financial Crisis Since the Great Depression, 15 MARQ. InTELL. Prop. L. REV. 449, 451 (2011).

283. Our History, U.S. SMALl BuS. ADMIN., http://www.sba.gov/about-sba/what_we_do/ history (last visited Oct. 10, 2014), archived at http://perma.cc/J3Y2-3EJQ. 
provides loans, loan guarantees, and counseling to small businesses across the countries. ${ }^{284}$ Railex Corp. v. Joseph Guss \& Sons, Inc. is an illustrative example of lending to small businesses and taking intellectual property assets, including patent applications, as security. ${ }^{285}$

On November 21, 1961, Railex borrowed money from SBA and signed a document wherein it transferred title of the patent applications to the SBA. ${ }^{286}$ The document provided that the assignment would be null and void if Railex fulfilled its payment obligations pursuant to the promissory note. ${ }^{287}$ The note was due to mature on November 21, $1971{ }^{288}$ Railex, however, repaid the loan in full on July 31, 1964. ${ }^{289}$ On August 21, 1964, Railex brought a patent infringement suit against Joseph Guss \& Sons, Inc. ${ }^{290}$ The defendants sought to dismiss the suit, arguing that SBA was the indispensable party to the suit. ${ }^{291}$

The court observed that the conditional assignment of the patent applications for security of the note was a mortgage transaction similar to the patent mortgage transaction in the Waterman v. Mackenzie case. ${ }^{292}$ The court recognized that under Waterman, the mortgagee holding a patent enjoys the entire title, both equitable title and legal title, to the patent collateral and can bring an infringement suit against others. ${ }^{293}$ The court, however, distinguished its facts from Waterman, noting that the mortgagor in Waterman did not repay the loan at the time it filed the patent infringement suit, whereas the mortgagor in the present case, Railex, had paid the loan in full prior to filing the patent infringement law suit. ${ }^{294}$

Consequently, Railex reacquired equitable title to the mortgaged patents on

284. Id.

285. Railex Corp. v. Joseph Guss \& Sons, Inc., 40 F.R.D. 119 (D.D.C. 1966) aff'd, 382 F.2d 179 (D.C. Cir. 1967); see also Magnuson Indus., Inc. v. Co-Rect Prods., Inc., No. 4-78-112, 1981 WL 48193, at *5 (D. Minn. Jan. 14, 1981) (finding that the transaction between Conry did not "involve usual type of patent assignment because the SBA held title to the patent only as a mortgagee. When the loan debt was compromised, it relinquished its rights as mortgagee by returning to Conry the written instrument of assignment.").

286. Railex Corp., 40 F.R.D. at 122.

287. Id. at 121 (noting that the document signed by Railex contained relevant provisions for the conditional assignment of the patent applications: "Provided always, and this assignment is made upon the express condition that if the Assignor shall punctually and fully pay or cause to be paid unto SBA the full amount payable upon or with respect to said note, according to its terms, together with interest thereon $* * *$ this assignment shall be null and void, and said Letters Patent and applications for Letters Patent shall be reassigned to the Assignor but shall otherwise remain in full force and effect.").

288. Id.

289. Id. at 122 (noting that the promissory note "was stamped 'PAID', signed, and dated by the authorized SBA certifying officer on that date").

290. Id. at 121 .

291. Id. at 122-23.

292. Id. at 122 .

293. Id.

294. Id. 
July 31, 1964, when the loan from the SBA was repaid in full. ${ }^{295}$ SBA continued to hold the bare legal title in the mortgaged patents until April 26, 1965. ${ }^{296}$ SBA held the bare legal title after Railex paid off the loan and before the total release of the "assignment" pursuant to the instrument, "as constructive trustee for the benefit of plaintiff-mortgagor, but no longer as security for the SBA loan, which had been repaid in full on July 31, 1964."297 Therefore, Railex had standing to bring the infringement suit against the defendants and SBA, "as holder of bare legal title to the patents in suit" as of the complaint filing date, "is neither an indispensable nor a necessary party in the present" patent infringement suit "in the nature of a suit in equity." ${ }^{298}$

This case is important on several fronts. It shows that small businesses are in need of financing. ${ }^{299}$ Access to credit is crucial to the survival of the business. ${ }^{300}$ It demonstrates that small businesses do not have the real estate property for security of loans. ${ }^{301}$ What small businesses do have is intellectual property. ${ }^{302}$ When making loans to small businesses, SBA and private lending institutions recognize this reality and take intellectual property, including patent applications, as security for loans. ${ }^{303}$ In addition, this case follows Waterman $v$. Mackenzie to vest the intellectual property mortgagee with the entire title in the mortgaged intellectual property during the time the intellectual property serves

295. Id.

296. Id. ("Legal title, however, continued to be held by mortgagee SBA until April 26, 1965, at which time legal title was reassigned to the plaintiff-mortgagor by SBA with a provision in this second assignment that 'this assignment includes the right to sue and recover for past infringements, against all persons or parties except the United States Government and its Agencies.").

297. Id. at 122-23.

298. Id. at 126; see also id. at 123 ("In the present case plaintiff has prayed for injunctive relief and for an equitable accounting for profits, as well as incidental legal relief in the form of an award of money damages, and this case is, therefore, essentially a civil non-jury action for patent infringement in the nature of a suit in equity.").

299. See generally id. (showing that the SBA, in providing financing to smaller businesses, resorted to the intellectual property of said companies as securities for their loans).

300. The United States government recognized that businesses were hurt by the Great Depression. Our History, supra note 283. In 1932, which was before the SBA was in existence, the government created the Reconstruction Finance Corporation (RFC) to lend to big businesses. Id. (explaining early versions of SBA). RFC, in its lending practices, took intellectual property assets, among other property, as security for loans. See Horowitz v. Kaplan, 193 F.2d 64, 69 (1st Cir. 1951) ("RFC loan was reduced to the sum of $\$ 1,500,000$ by payments on account, the balance of the loan being extended to December 31,1960 , secured solely by a mortgage on the plant, machinery, equipment, good will, trade-marks and patents of the debtor.").

301. See Railex Corp., 40 F.R.D. at 121-22.

302. See id.

303. See generally Horowitz, 193 F.2d at 69 (demonstrating that RFC issued a loan which was secured in part by a mortgage on the trademarks and patents of the debtor). 
as security for the outstanding loan. ${ }^{304}$ In other words, the ruling in this case encourages financing secured by intellectual property assets. ${ }^{305}$

\section{Secured Party of IP Collateral as OWNer by Operation of LaW}

Modern secured transactions law specifies what the secured party's rights are in the event the debtor fails to fulfill payment obligation or is in default. ${ }^{306}$ The secured party can foreclose on the collateral and dispose of the collateral for purposes of recovering as much as it can on the loan. ${ }^{307}$ With tangible collateral, the secured party can enter the debtor's premise and seize the collateral as long as the repossession is conducted without breaching the peace. ${ }^{308}$ Alternatively, the secured party can obtain a judicial order to repossess the collateral, but this process is both costly and inefficient. ${ }^{309}$ Upon having the possession of the collateral, the secured party can conduct either a public or private sale of the collateral. $^{310}$ With intellectual property collateral, foreclosure has its own challenges. ${ }^{311}$ Repossession with the self-help method for tangible property cannot be applied to intellectual property as they are intangible in nature. ${ }^{312}$ The question, then, is must the secured party request that the debtor execute an assignment of the foreclosed intellectual property to the secured party and record the assignment with the Patent Office before the secured party can transfer the intellectual property to a purchaser? What should the law be in addressing the above challenge in order to encourage financing with intellectual property as collateral?

The case Sky Technologies v. SAP is both instructive and contributive in the

304. See supra note 29 and accompanying text (explaining that the mortgagee holds entire title to the patents acting as a security).

305. See Railex Corp., 40 F.R.D. at 121-22.

306. See generally U.C.C. $\S 9$, Pt. 6 (2000).

307. Id. § 9-610 ("After default, a secured party may sell, lease, license, or otherwise dispose of any or all of the collateral in its present condition or following any commercially reasonable preparation or processing.").

308. Id. § 9-609 (providing that after default, "a secured party: (1) may take possession of the collateral" . . . "pursuant to judicial process; or without judicial process, if it proceeds without breach of the peace").

309. Mark G. Yudof, Reflections on Private Repossession, Public Policy and the Constitution, 122 U. PA. L. REV. 954, 964-65 (1974) (reporting that the cost of replacing self-help repossession with judicial means would be $\$ 143$ million per year); James White, The Abolition of Self-Help Repossession: The Poor Pay Even More, 1973 WIS. L. REV. 503, 520-22 (conducting seminal costbenefit study of self-help repossession).

310. U.C.C. $\S 9-610$ (b) (2000) ("If commercially reasonable, a secured party may dispose of collateral by public or private proceedings").

311. See Julie E. Cohen, Copyright and the Jurisprudence of Self-Help, 13 BERKELEY TECH. L.J. 1089, 1120 (1998).

312. Id. 
development of the intellectual property secured financing law. ${ }^{313}$ In Sky Technologies, Ozro, Inc. owned a portfolio of patents and sought financing from Silicon Valley Bank ("SVB"). ${ }^{314}$ On April 1, 2001, Ozro executed an Intellectual Property Security Agreement with SVB, granting the bank a "security interest in all of Grantor's right, title, and interest, whether presently existing or hereafter acquired in, to and under all of the Collateral." ${ }^{15}$ The collateral included the patent portfolio, and SVB filed the agreement with the United States Patent and Trademark Office on the same day. ${ }^{316}$

On the next day, Ozro signed a similar security agreement with Cross Atlantic Capital Partners, Inc. ("XACP"). ${ }^{317}$ The security agreement contained identical provisions as the agreement between Ozro and SVB. ${ }^{318}$ In both agreements, Ozro used the patent portfolio as collateral to secure the loans. ${ }^{319}$ In the event of default by Ozro on the loans, both SVB and XACP have "the right to exercise all the remedies of a secured party upon such default under the Massachusetts UCC," including the right to repossess and dispose the intellectual property collateral. ${ }^{320}$ In addition, Ozro was required to "assemble the Intellectual Property Collateral and any tangible property in which [SVB or XACP] has a security interest and to make it available to [SVB or XACP]." ${ }^{" 321}$

A year and a half later, in December 2002, SVB assigned its security interest under the SVB Agreement with Ozro to XACP through a non-recourse assignment, giving XACP all of the "right, title, and interest" formerly held by SVB. ${ }^{322}$ XACP recorded the assignment with the United States Patent and Trademark Office. ${ }^{323}$ XACP still held its own existing security interest in Ozro's patent portfolio collateral. ${ }^{324}$

A few months later, Ozro defaulted on the loan, and XACP foreclosed on the assets, including the patents. ${ }^{325}$ On July 14, 2003, upon foreclosure and after notifying all parties with interest in the patents, XACP sold the patents at public

\footnotetext{
313. Sky Techs. LLC v. SAP AG, 576 F.3d 1374 (Fed. Cir. 2009).

314. Id. at 1376.

315. Id.

316. Id.

317. Id. at 1377.

318. Id.

319. Id.

320. Id. (noting that both agreements provide that the secured party: "(i) to take possession of all or any portion of the Intellectual Property Collateral, (ii) to sell, lease, or otherwise dispose of any or all of the Intellectual Property Collateral ... and (iii) to exercise all or any of the rights, remedies, powers, privileges and discretions under all or any of the documents relating to the Secured Obligations").

321. Id. (alteration in original).

322. $I d$.

323. $I d$.

324. Id.

325. Id. at 1378.
} 
auction. ${ }^{326} \mathrm{XACP}$ was the only bidder and purchased all of the assets, including the patents. ${ }^{327}$ During the foreclosure and disposition process, Ozro never executed a written agreement assigning all of its rights, title or interests in the assets, including the patents to XACP. ${ }^{328}$ Subsequently, XACP assigned the patents to Sky Technologies. ${ }^{329}$ Three years later, in 2006, Sky Technologies brought a patent infringement suit against SAP who then moved to dismiss the suit, asserting that Sky Technologies had no standing because Ozro had never assigned its rights in the patents to XACP. ${ }^{330}$

The district court held for Sky Technologies and granted SAP's Motion for Certification of Question for Interlocutory Appeal to the Federal Circuit based on a finding that "substantial grounds for difference of opinion exist regarding the question of whether a transfer of title through operation of law without a written assignment may apply in situations that do not involve heirs or probate law." 331

The Federal Circuit emphasized that the central question was whether XACP had right, title, and interest in the patents to transfer all of those rights to Sky Technologies. ${ }^{332}$ The court looked to Massachusetts UCC Article 9 to determine XACP's ownership in the patents. ${ }^{333}$ The court determined that under Massachusetts UCC section 9-610, XACP, as a secured party, had the right to dispose of the collateral in a commercially reasonable manner after the debtor, Ozro, was in default. ${ }^{334}$ XACP was allowed under Article 9 to purchase the collateral at a public disposition. ${ }^{335}$ Further, under UCC section 9-617, upon acquiring the collateral at the disposition, the transferee for value takes all of the debtor's rights in the collateral. ${ }^{336}$ Accordingly, "[b]ecause XACP foreclosed on the patents-in-suit in conformity with these provisions, XACP obtained title to the patents on July 14, 2003." 337 XACP became the new owner of the patents as "[n]othing in the language of [Article 9] evinces the requirement that a writing must exist to transfer patent rights through operation of law," and it properly transferred its ownership to Sky Technologies. ${ }^{338}$ The Federal Circuit affirmed the district court's decision that Sky Technologies had indeed become the new owner of the patents through operation of law. ${ }^{339}$

The Federal Circuit provided policy justifications for permitting transfers of

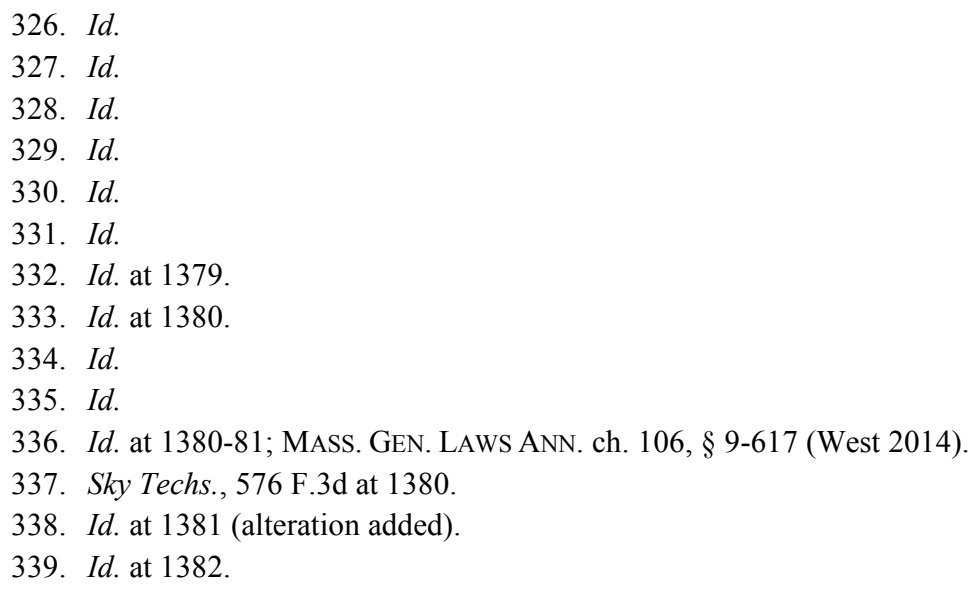


patent ownership through operation of law (i.e., foreclosure, disposition, and purchase of patents under UCC Article 9) without the parties having to memorialize the transaction in writing. ${ }^{340}$ Notably, the writing requirement would negatively impact existing secured financing with patents as collateral, hinder future financing with patent collateral, and impose burden on transactions:

First, if foreclosure on security interests secured by patent collateral could not transfer ownership to the secured creditor, a large number of patent titles presently subject to security interests may be invalidated. Any secured creditor who maintained an interest in patent collateral would be in danger of losing its rights in such collateral. Second, by restricting transfer of patent ownership only to assignments, the value of patents could significantly diminish because patent owners would be limited in their ability to use patents as collateral or pledged security. Lastly, it would be impractical to require secured parties to seek out written assignments following foreclosure from businesses that may have ceased to exist. ${ }^{341}$

The Federal Circuit's legal and public policy explanations mark an important development in the law relating to financing with the use of intellectual property as collateral. ${ }^{32}$ With certainty, a secured party now can expect that in the event the debtor is in default, the secured party can become the owner of the intellectual property collateral by operation of law as long as the secured party properly disposes and purchases the collateral in accordance with Article 9 of the Uniform Commercial Code. ${ }^{343}$ The secured party's ownership of the intellectual property by operation of law reduces unnecessary costs in searching and demanding for the debtor's signature. ${ }^{344}$ The recognition also enhances the value of the intellectual property because the purchaser can trust that the chain of title of the intellectual property has not been broken. ${ }^{345}$ The purchaser is the new owner, as it has bought from the secured party with ownership of the intellectual property by operation of law. ${ }^{346}$ In summary, Sky Technologies v. SAP recognizes the importance of secured transactions today with intellectual property collateral and adheres to the purposes of UCC Article 9 in encouraging secured financing. ${ }^{347}$

340. Id. at $1381-82$.

341. Id.

342. See id. at 1380-81.

343. Id. ("[C]onsistent with sections 9-610 and 9-617, XACP received all of Ozro's rights in the Collateral, making XACP the title-holder of the patents-in-suit after foreclosure.”).

344. See id.

345. See id.

346. See id.

347. If the secured party in a foreclosure sale of the patent collateral failed to properly list the patents in the sale notice, some courts may not approve the validity of the sale. See Mayfair Wireless LLC v. Celico P'ship, No. 11-772-SLR-SRF, 2013 WL 4657507, at*6 (D. Del., Aug. 30, 2013) (finding that "[n]one of the above-listed evidence identifies the " 441 patent application specifically, and as a result, the court declines to assume that the rights to the application for the 


\section{SECUREd PARTY's RisKs RELATED to IP COLLATERAL}

Providing financing to businesses involving intellectual property assets does present some risks to secured creditors. ${ }^{348}$ As intellectual property assets have become increasingly valuable corporate assets, many companies aggressively assert infringement against third parties. ${ }^{349}$ The cost of infringement litigation is high and a disruptive threat to the operation of the business. ${ }^{350}$ From the secured creditor's perspective, in addition to the risk of nonperforming loans and the difficulty of obtaining an accurate valuation of intellectual property assets, there are at least two additional types of risks: (1) whether a grant of a security interest in some circumstances can be deemed a fraudulent transfer; and (2) whether the secured creditor is liable for infringement. ${ }^{351}$

\section{A. Fraudulent Transfers}

Aptix Corp. v. Quickturn Design Systems, Inc. is a cautionary tale for all investors who pour their own financial resources to finance their own startups and take a security interest in the startup's intellectual property. ${ }^{352} \mathrm{Dr}$. Amr Mohsen developed hardware-logic-emulation technology and was the inventor of certain patents. ${ }^{353}$ Dr. Mohsen founded the company, Aptix, and was the majority shareholder, chief executive officer, and chairman of the company. ${ }^{354}$ Like many other startups, the company was in financial trouble due to unsuccessful attempts to borrow money, raise equity financing from outside investors, and merge with another company. ${ }^{355}$ Dr. Mohsen used his own financial resources to make at least $\$ 2$ million in loans to the company. ${ }^{356}$ These loans were unsecured; they did

'441 patent were included in the foreclosure sale").

348. See Aptix Corp. v. Quickturn Design Sys., Inc., 148 F. App'x 924 (Fed. Cir. 2005); Van Well Nursery, Inc. v. Mony Life Ins. Co., 362 F. Supp. 2d 1223, 1224 (E.D. Wash. 2005); Lex Machina, Releases First Annual Patent Litigation Year in Review, LEX MACHINA (May 13, 2014), https://lexmachina.com/2014/05/patent-litigation-review/, archived at http://perma.cc/8XHXZXE7; Jim Kerstetter, How Much is that Patent Lawsuit Going to Cost You?, CNET (Apr. 5, 2012, 10:00 AM), http://www.cnet.com/news/how-much-is-that-patent-lawsuit-going-to-cost-you/, archived at http://perma.cc/7L89-UF44.

349. See Machina, supra note 348 (explaining that over 6,000 patent lawsuits were filed in 2013, which is a twelve percent increase from the previous year).

350. See Kerstetter, supra note 348 (noting that according to the American Intellectual Property Law Association, the average legal costs for a patent infringement claim between $\$ 1$ million and \$25 million dollars is approximately \$2.5 million).

351. See Aptix, 148 F. App'x at 929-30; Van Well Nursery, 362 F. Supp. 2d at 1224.

352. Aptix, 148 F. App'x at 924.

353. $I d$. at 925 .

354. Id. at 926 .

355. Id.

356. Id. 
not have any property as security. ${ }^{357}$ The company's situation did not improve and Dr. Mohsen then loaned at least $\$ 9.7$ million between July 2000 and September 2003 to the company. ${ }^{358}$ These loans were secured by the company's assets, including the patents; Dr. Mohsen received a grant of security interest in the collateral. ${ }^{359}$ The company used these loans to pay employees, vendors, and creditors and to "keep the company alive and operating." 360 During the time of the security interest grant, the company was in a patent infringement action against a competitor and expected to receive an adverse judgment. ${ }^{361}$ The competitor sought to levy against the company's assets that had already been encumbered to Dr. Mohsen's security interest. ${ }^{362}$

However, the Federal Circuit's majority panel held that "the making of a secured loan instead of an unsecured loan in anticipation of an adverse judgment establishes deliberate wrongful conduct" and concluded that Dr. Mohsen's security interest in the patents was a fraudulent transfer by the company. ${ }^{363}$ The majority panel affirmed the district court's decision to void Dr. Mohsen's security interest in the patents. ${ }^{364}$

Whether one agrees with the panel's majority is not material here. What is important is accessing potential risks to the secured party. As seen in this case, routine business financing can be disregarded and labeled as a fraudulent transfer to the detriment of the lenders. ${ }^{365}$ In providing financial resources to a startup, an investor-as-secured-creditor must be aware of how courts view the investor's conduct in determining whether the financing with intellectual property used as collateral is legitimate. ${ }^{366}$

\section{B. Infringement Liability}

Another type of risk is infringement liability. ${ }^{367}$ This risk occurs if the secured lender extends credit to a borrower, takes a security interest in the borrower's property and assets, and then forecloses on collateral, which includes products that are the subject of a patent infringement suit asserted by the patentee

357. $I d$.

358. Id.

359. Id.

360. Id.

361. Id.

362. Id. at 927 .

363. Id. at 932 (Newman, J., dissenting) ("The moneys obtained and the security interest granted for the loan were routine business practice. The secured nine million dollars here loaned provided essential funds to pay employees, vendors, and creditors. The facts of record do not establish fraud under California statute and precedent.").

364. Id. at 930 .

365. Id. at 931-32.

366. See id. at 930-32.

367. See Van Well Nursery, Inc. v. Mony Life Ins. Co., 362 F. Supp. 2 d 1223 (E.D. Wash. 2005). 
against others, including the borrower. ${ }^{368}$ The question arises whether the secured creditor is liable for infringement, either under the direct infringement or contributory infringement theory. ${ }^{369}$

Van Well Nursery, Inc. v. Mony Life Insurance Co. illustrates a secured creditor's potential patent infringement liability risk. ${ }^{370}$ Van Well owned a particular patent for a new apple tree variety and sold the patented trees to the public. ${ }^{371}$ On July, 9, 2004, Van Well brought a patent infringement action against A/B Hop Farm and Mony Life Insurance ("Mony Life"). ${ }^{372}$ Mony Life had periodically made large loans to A/B Hop Farm from 1991 to $1996 .{ }^{373}$ In February, 1996, Mony Life loaned \$2.5 million to A/B Hop Farm for the purchase of Wallula Orchard Properties and the loan was secured by the Wallula Orchard Properties. ${ }^{374}$ The parties signed the mortgage agreement. ${ }^{375}$ Thereafter, A/B Hop Farms defaulted on the loan and Mony Life foreclosed on all property collateral, including Wallula Orchard Properties. ${ }^{376}$

Van Well asserted that because Wallula Orchard Properties had planted apple trees that infringed on the patent at issue, Mony Life was liable based on the mortgage document between A/B Hop Farm and Mony Life. ${ }^{377}$ Van Well relied on certain provisions in the mortgage document to advance its infringement theory against Mony Life. ${ }^{378}$ Specifically, the mortgage agreement provided that the mortgagor, in order to secure the payment of the \$2.5 million dollar loan, "mortgages, assigns and warrants" to the mortgage lender, Mony Life, the Wallula land

together with numerous other interests including for example the buildings, improvements, fixtures, permanent plantings, crops and other farm products, rents, profits, income and proceeds therefrom, contract rights, water rights, all judgments, awards of damages, settlements and payments made for any taking of the property or damage to the property, and a security interest in all irrigation, frost control and orchard cooling facilities. ${ }^{379}$

The mortgage agreement also stated that the conveyances would be null and void, but only if the mortgagor made all payment obligations and performed all

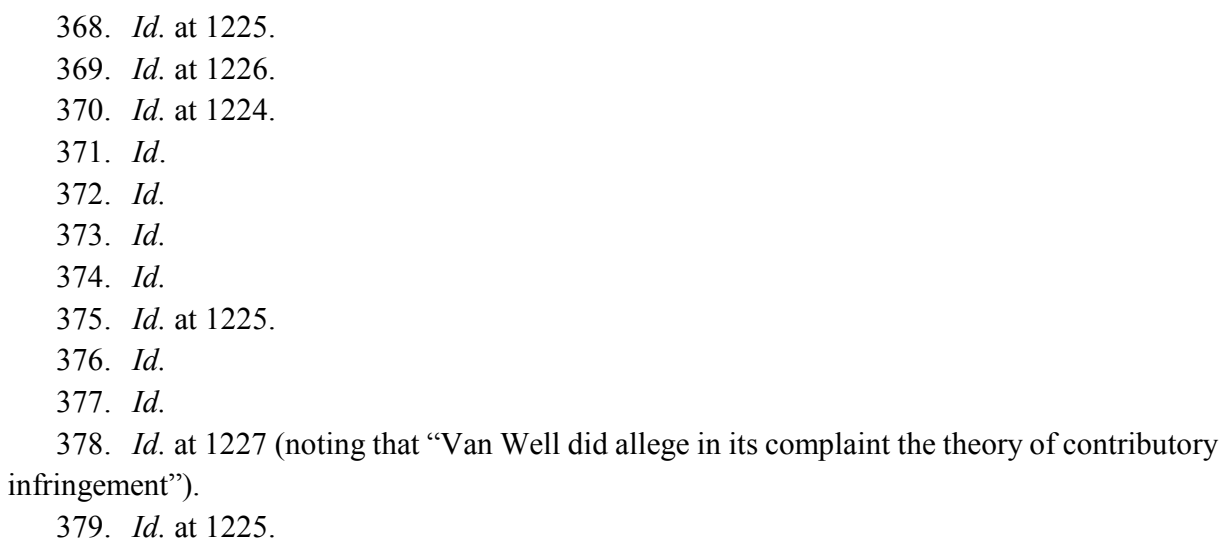


covenants in the agreement. ${ }^{380}$ In the event that the mortgage was in default, the mortgage agreement provided Mony Life with recourse to protect its security interests in the property. ${ }^{381}$ Mony Life countered that these provisions were "standard" in agricultural secured lending business. ${ }^{382}$

The court analyzed the direct infringement claim after it quickly disposed the contributory infringement claim for lack of evidence. ${ }^{383}$ The court first noted that Van Well raised an issue of first impression of a mortgage lender's liability for patent infringement. ${ }^{384}$ This issue required an examination of whether the mortgage lender's conduct falls within "use" of the patent. ${ }^{385}$

The inquiry on "use" of the patent is a factual inquiry on case-by-case basis. ${ }^{386}$ Van Well advanced a theory of direct infringement on the part of the mortgage lender by urging the district court to interpret the term "use" broadly and accept the theory of "constructive use" that Mony Life "should be held liable because it had an ability to act with respect to the infringing trees and it possessed sufficient rights that it 'could [have affected] the infringing activity if it so chose." 387 Van Well cited to a number of cases to support its argument, but the district court rejected them because their facts were distinguishable from the case at bar. ${ }^{388}$ Crucially, the cited cases involved actual conduct involving the infringing product, actual control over, and possession of the infringing product. ${ }^{389}$ Here, the district court noted that Mony Life "did not have, nor could have had" the infringing apple trees. ${ }^{390}$ Therefore, Mony Life could not "use" the patent because "how could one use an item it does not have?"391 More specifically, Mony Life could, as a secured creditor to secure the loans it made to the borrower, "demand rights and performance of obligations in order to assure the collateral pledged is maintained." ${ }^{392}$ The district court observed that "[i]f having these rights, without their actual exercise, was considered 'use' of the property itself then no secure creditor would ever be protected." 393

The court emphasized that holding a lending institution liable for direct infringement under the facts in this case would threaten the foundation of a dynamic, competitive, and stable economy and other threats:

380. $I d$.

381. Id.

382. Id.

383. Id. at $1227-30$.

384. Id. at 1228 (noting that "Van Well is correct in acknowledging the issue of a mortgage lender's liability for plant patent infringement is one of first impression").

385. Id. at 1227-28.

386. Id. at 1229 .

387. Id.

388. Id.

389. Id.

390. Id.

391. Id.

392. Id.

393. Id. 
[A]t a minimum it would create tremendous apprehension and uncertainty in lending, instill additional disincentives to lend and discourage productive enterprises, and perhaps threaten the very foundation of the agricultural lending industry and the economy it serves. The costs associated with defending against an intellectual property infringement suit and any liability associated therewith could easily exceed the amount originally at stake in the underlying transaction. ${ }^{394}$

Congress, not courts, was the appropriate body for Van Well to seek the extension of its patent protection against mortgage lenders. ${ }^{395}$ Accordingly, Mony Life's authority to control Wallula Orchard property pursuant to the mortgage agreement failed to support Van Well's claim of direct infringement against Mony Life. ${ }^{396}$

The court clarified that its decision was not dictated by Mony Life's argument that the provisions in the mortgage agreement were merely "standard" in the agricultural secured lending business. ${ }^{397}$ The court warned that "standard" lender behavior is "a mutable concept, and it will respond to the liability rules the Courts and Congress put into place." ${ }^{.398}$ However, "[i]n this context, while lenders may offer deep-pocket appeal to the patent holder, lender liability has not been met with widespread judicial acceptance in most tort-liability scenarios." ${ }^{, 399}$

Moreover, the court rejected Van Well's request for a declaration that Mony Life's security interest in any of the allegedly infringing trees in Wallula Orchard be voided and the infringing trees ordered destroyed. ${ }^{400}$ The court denied the request for lack of support in patent law. ${ }^{401}$

In summary, there are two identifiable risks that a secured creditor may face in financing innovation. ${ }^{402}$ First, a grant of security interest in some circumstances could be deemed as a fraudulent transfer. ${ }^{403}$ This risk can be minimized in self-financing cases by routinely taking a security interest when the self-financier provides a loan to his or her company. This consistent behavior will reduce the inference of fraudulent conveyance stemming from selective granting and receiving security interests. Second, the secured creditor is liable for infringement. ${ }^{404}$ This risk is very rare in financing innovation by the private

394. Id. at 1230 .

395. Id.

396. Id.

397. Id. at 1229-30.

398. Id. at 1229.

399. Id.

400. Id. at 1230 .

401. Id.

402. See Aptix Corp. v. Quickturn Design Sys., Inc., 148 F. App’x 924, 931-32 (Fed. Cir. 2005); Van Well, 362 F. Supp. 2d at 1229-30.

403. Aptix Corp., 148 F. App'x at 931-32.

404. See Van Well, 362 F. Supp. 2d at 1223. 
sector and can be minimized through careful drafting of the security agreement. ${ }^{405}$

\section{SOME IMPLICATIONS FROM HISTORICAL FINANCING INNOVATIONS}

Technological advancements in the United States have profoundly changed every sector of the economy since the United States Supreme Court decided Waterman v. McKenzie, recognizing the use of intellectual property assets as security in business financing. ${ }^{406}$ The loan secured by two patents in 1891 represents the quintessential American system of supporting small businesses, as patents are major contributors to innovation and job creation. ${ }^{407}$

Along with technical advancements, not surprisingly, there are new means for businesses today to obtain financing. ${ }^{408}$ Equity financing and crowdfunding are two examples. ${ }^{409}$ In broad terms, in equity financing, investors will acquire shares or equity in the business in exchange for the investment provided by the investors to the business. ${ }^{410}$ Equity financing allows businesses to have access to capital on a small and large scale. ${ }^{411}$ Equity financing has its shortcomings; founders of businesses in equity financing are generally concerned about their loss of control or direction of the company. ${ }^{412}$ Crowdfunding leverages the ease

405. See Nguyen, supra note 17, at 36 n.186 (discussing suggested language for security agreements).

406. Waterman v. Mackenzie, 138 U.S. 252, 260 (1891).

407. Jay M. Mattappally, Goliath Beats David: Undoing the Leahy-Smith America Invents Act's Harmful Effects on Small Businesses, 58 LoY. L. REV. 981, 983 (2012) ("small businesses have been the stabilizing force in the economy for years, as well as its primary economic growth stimulator" and "are very important to innovation").

408. See C. Steven Bradford, Crowdfunding and the Federal Securities Laws, 2012 CoLuM. Bus. L. REV. 1, 5 (2012); John Floegel, Equity Financing for Public Corporations: Reasons and Methods to Encourage It, 138 U. PA. L. REV. 1411, 1418 (1990).

409. See Floegel, supra note 408, at 1418 ("Equity financing enables corporations to raise money by selling ownership interests (represented by shares of stock) to investors"); Bradford, supra note 408 , at 5 .

410. See George Deeb, Comparing Equity, Debt and Convertibles for Startup Financings, FORBES (Mar. 19, 2014, 2:25 PM), http://www.forbes.com/sites/georgedeeb/2014/03/19/comparingequity-vs-debt-vs-convertibles-for-startup-financings/, archived at http://perma.cc/V94L-RGWX (discussing advantages and disadvantages of equity financing).

411. See Debt vs. Equity Financing: Which Is the Best Way for Your Business to Access Capital?, NAT'L FED'N OF INDEP. BUS. (Oct. 17, 2009), http://www.nfib.com/article/ital-50036/, archived at http://perma.cc/5EKU-YALE (discussing advantages of equity financing, which include having more money on hand to expand one's business).

412. See, e.g., Small Business Financing: Debt vs. Equity, AdVISOR SQUare (Mar. 2013), http://www.advisorsquare.com/new/LPL_Library/March_2013_Independent_Investor.pdf?advis orid $=3005068$, archived at $\mathrm{http}: / /$ perma.cc/3P8B-22ZJ (providing pros and cons of small business financing relating to debt versus equity); Financing a Small Business: Equity or Debt?, ForBES (Jan. 1, 2007, 4:30 PM), http://www.forbes.com/2007/01/05/equity-debt-smallbusiness-ent-fincx_nl_0105nolofinancing.html, archived at http://perma.cc/NWQ6-3VRU (providing advantages 
of mobile online communication to enable businesses to present their nascent ideas for funding from the crowd or supportive online users. ${ }^{413}$

Despite these new methods to obtain financing, small businesses in the United Sates have been struggling to gain access to credit. ${ }^{414}$ The recent financial crisis and its aftermath continue to limit the ability of businesses to obtain credit. ${ }^{415}$ Banks are still not eager to lend to small businesses, as the numbers show a twenty percent decline in small business lending since the financial crisis. ${ }^{416}$ Most troubling, access to credit for small businesses was already in steady decline prior to the financial crisis. ${ }^{417}$

A few online lenders have begun to enter the small business lending sector and utilize technological sophistication to ration their loans to small businesses. ${ }^{418}$ They use innovative software and data metrics from social media interactions and Yelp comments to analyze a potential borrower's application for a loan. ${ }^{419}$ Their analytic system, however, ignores the borrower's intellectual property assets. ${ }^{420}$

The lessons learned from the history of legal development for financing innovation suggests that there is a need for both traditional and online lenders to appreciate the intellectual property assets held by small businesses. The intellectual property assets should be included in the analytics in assessing the overall health of a business seeking a loan or a line of credit. Lenders should take comfort in decisional laws that have consistently encouraged financing when intellectual property assets serve as collateral. ${ }^{421}$ The long history of courts

and disadvantages of equity financing and borrowing money option); Asheesh Advani, Choosing Between Debt and Equity Financing, EnTrepreneur (Apr. 3, 2006), http://www.entrepreneur.com/article/159518, archived at http://perma.cc/3NWM-LSQA (explaining why businesses need to choose investors for equity financing with care).

413. Kickstarter is a major platform for crowdfunding of a wide range of projects. KICKSTARTER, https:/Www.kickstarter.com/ (last visited Oct. 8, 2014), archived at http://perma.cc/9L32-ED2W. Some promising projects began with crowdfunding then moved on to obtain equity funding from venture capitalists. See Joshua Brustein, How Kickstarter Turned Into the Venture Capitalist's Best Friend, BloOMBerg Business WeEK (Aug. 11, 2014), http://www.businessweek.com/articles/2014-08-11/kickstarter-successes-pivot-from-crowdfundingto-venture-capital, archived at http://perma.cc/6WYM-RE6H (discussing Kickstarter's involvement in both crowdfunding and equity funding).

414. Mills \& McCarthy, supra note 4, at 4.

415. Id.; see also Phyllis Furman, Loan groan: In Spite of an Improving Economy, NYC Small Businesses Say They Can't Get Bank Loans, N.Y. DAILY News (May 12, 2014, 10:33 AM), available at http://www.nydailynews.com/new-york/loan-groan-spite-improving-economy-nycsmall-businesses-bank-loans-article-1.1788874\#ixzz3 A5sgWsKj, archived at http://perma.cc/U6YK-8NP4.

416. Mills \& McCarthy, supra note 4 , at 4.

417. Id.

418. Id. at 42-44.

419. Id. at 46 .

420. See id.

421. Van Well Nursery, Inc. v. Mony Life Ins. Co., 362 F. Supp. 2d 1223 (E.D. Wash. 2005); 
accepting different types of intellectual property as security in financing, recognizing perfection of security interests in intellectual property, and elevating a secured party as the owner of the foreclosed intellectual property by operation of law demonstrates a favorable legal ecosystem for lenders to extend credit to small businesses with trademarks, copyrights, trade secrets, and patents as parts of their assets available to serve as collateral.

\section{CONCLUSION}

Global competition is fierce. Access to financing for small businesses and recognition of intellectual property must be at the center of discussion of how the United States can maintain its innovative edge. Looking across the Pacific Ocean, China has embraced a comprehensive strategy to increase innovation by providing financing based on the intellectual property assets of businesses. ${ }^{422}$ However, China's intellectual property financing is beyond the scope of this Article and will be discussed in a separate article. The central issue remains: how will the United States fuel its small businesses in need of financing for innovation?

Aptix Corp. v. Quickturn Design Sys., Inc., 148 F. App’x 924 (Fed. Cir. 2005).

422. Joff Wild, Chinese Companies Have Secured Over $\$ 10$ Billion in Patent-Backed Loans Since 2008, Intellectual Asset Mgmt. (Mar. 4, 2014), http://www.iammagazine.com/blog/detail.aspx?g=7fd84e0c-af7a-4d28-ba91-746bbb44e318, archived at http://perma.cc/G4UD-8XUQ ("Chinese companies secured over $\$ 4$ billion . . . of credit against patent rights in 2013”). 